\title{
A Preliminary Archaeological and Historical Assessment of the Proposed Tenneco Pipeline Hidalgo to Victoria Counties, Texas
}

Thomas R. Hester

Center for Archaeological Research

Follow this and additional works at: https://scholarworks.sfasu.edu/ita

Part of the American Material Culture Commons, Archaeological Anthropology Commons, Environmental Studies Commons, Other American Studies Commons, Other Arts and Humanities Commons, Other History of Art, Architecture, and Archaeology Commons, and the United States History Commons

Tell us how this article helped you.

This Article is brought to you for free and open access by the Center for Regional Heritage Research at SFA ScholarWorks. It has been accepted for inclusion in Index of Texas Archaeology: Open Access Gray Literature from the Lone Star State by an authorized editor of SFA ScholarWorks. For more information, please contact cdsscholarworks@sfasu.edu. 


\section{A Preliminary Archaeological and Historical Assessment of the Proposed}

Tenneco Pipeline Hidalgo to Victoria Counties, Texas

\section{Creative Commons License}

\section{(c) (1) (8)}

This work is licensed under a Creative Commons Attribution-NonCommercial 4.0 International License 
A PRELIMINARY ARCHAEOLOGICAL AND HISTORICAL ASSESSMENT

OF THE PROPOSED TENNECO PIPELINE

HIDALGO TO VICTORIA COUNTIES, TEXAS

\author{
Edited by \\ Thomas R. Hester
}

with contributions by

Thomas C. Kelly, Elizabeth Frkuska,

A. Joachim McGraw and Fred Valdez, Jr.

Center for Archaeological Research

The University of Texas at San Antonio

Archaeological Survey Report, No. 51

1979 
TABLE OF CONTENTS

Page

List of figures....................

List of Tables ........................ $i i_{i}$

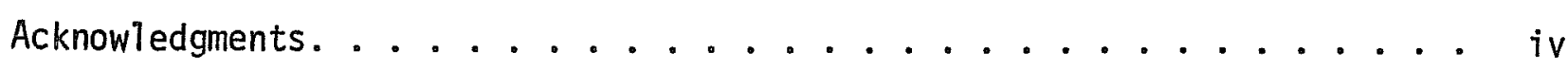

Preface (Thomas R. Hester) ................ v

I. Archaeological Summary of Previously Recorded Sites in the

Proposed Pipeline Route (A. Joachim McGraw and Fred Valdez, Jr). . . 1

II. Results of Field Inspection of Pipeline Route (Thomas C. Kelly). . . 9

III. Research Bibliography: Prehistoric and Historic Aboriginal

Cultures (Fred Valdez, Jr.)............. 22

IV. Historical Assessment of the Proposed Pipeline Route (Elizabeth

Cantu Frkuska) ............... . . 31

V. Research Bibliography: History (Elizabeth Cantu Frkuska). . . . . 42 


\section{LIST OF FIGURES}

Figure

Page

1. Map of Tenneco Pipeline Route .............. 2

2. Tenneco MP 41, Looking South. ............... 11

3. Tenneco MP $63 \ldots \ldots \ldots 11$

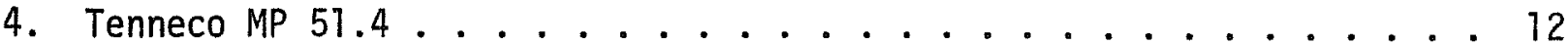

5. Tenneco MP 82.70 Laguna Salada. . . . . . . . . . . 12

6. Tenneco MP 82.70.................... 14

7. Tenneco MP 82.70...................... 14

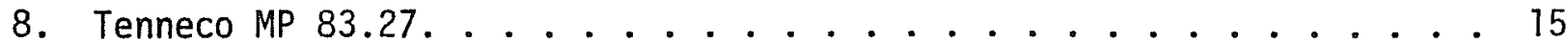

9. Potential Archaeological Site ........... 15

10. Tenneco MP 132.4..................... 16

11. North Bank of Nueces River. . . . . . . . . . . . . . 16

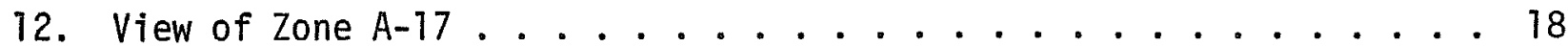

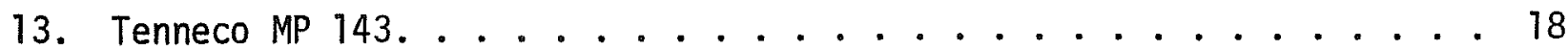

14. Selected Artifacts. .................. 21 


\section{LIST OF TABLES}

Table

1. Archaeological Sites Previously known and Recorded during Survey, Proposed Pipeline Route. . . . . . . . . . . . . . 4

2. Archaeologically Sensitive Zones Along the Proposed PipeTine Route in Texas................ 5

3. Historical Sites in Hidalgo County ............. 34

4. Historical Sites in Brooks County. . . . . . . . . . . . 36

5. Historical Sites in Jim Wells County ........... 37

6. Historical Sites in Kleberg County ............. 37

7. Historical Sites in Nueces County. . . . . . . . . . 38

8. Historical Sites in San Patricio County. . . . . . . . . 39

9. Historical Sites in Refugio County ............. 40

10. Historical Sites in Victoria County. . . . . . . . . . 41 


\section{ACKNOWLEDGMENTS}

The cooperation and support of this survey by the personnel of Tenneco, at both the staff and field level, has been exemplary. Mr. Richard E. Lyons, overall project coordinator, and Mr. Robert P. Otjen, survey coordinator, correctly anticipated all map and aerial photograph requirements and got the research project into the field without delay. Mr. Otjen also provided helicopter coverage, a tremendous aid in our preliminary evaluation of the cultural resources of the proposed pipeline route.

Mr. B. N. Duckett, District 9 Superintendent, and Mr. T. Elledge, District 1 Superintendent, showed their interest in the success of the survey, made valuable suggestions and provided their most experienced men as guides to the more difficult sections of their districts. Herb Narum, Rube Coggans, Irwin Hensa1, Jim Gault and F. A. Schubert each spent one or more days with Thomas C. Kelly in the field. Their detailed knowledge of the terrain insured a better preliminary survey in a minimum amount of time.

Anne A. Fox provided excellent guidance and references to source material for the historical survey. 


\section{PREFACE}

This report constitutes a preliminary assessment of the archaeological and historical resources along the proposed route of the natural gas pipeline being planned by Tenneco, Inc. The report is submitted in partial fulfillment of a contract between Tennessee Gas Pipeline (Division of Tenneco, Inc., Houston) and The University of Texas at San Antonio, Center for Archaeological Research. Submitted separately to Tennessee Gas Pipeline is a large strip map showing the location of the proposed pipeline; on this map are plotted all historic and prehistoric sites known to exist at the time of the completion of this preliminary assessment. As the text of this report indicates, a number of areas remain to be intensively surveyed and investigated.

The research reported here followed guidelines set forth in a letter from $\mathrm{Mr}$. William Such (Tennessee Gas Pipeline) of August 1, 1977. The scope of work outlined in his letter has been fulfilled. Known archaeological and historical resources have been assembled, limited field inspections have been made, and recommendations are contained herein for future archaeological and historical work. It is our present belief that the problem areas identified in this report will not necessitate the development of plans for any alternate pipe1 ine routes.

I served as Project Director during this assessment. Thomas C. Kelly conducted the field inspections and collaborated on the general archaeological assessment. Studies of known archaeological resources were done by A. Joachim McGraw and Fred Valdez, Jr. Elizabeth Cantu Frkuska prepared the historical sections. Research bibliographies also accompany this report, prepared by Valdez (prehistory) and Frkuska (history).

Thomas R. Hester 


\section{ARCHAEOLOGICAL SUMMARY OF PREVIOUSLY RECORDED \\ SITES IN THE PROPOSED PIPELINE ROUTE}

A. Joachim McGraw and Fred Valdez, Jr.

A preliminary archaeological and historical assessment of the projected Tennessee Atlantic Pipeline route from Hidalgo to Victoria Counties (Fig. 1) was undertaken during September-October 1977 by researchers from the Center for Archaeological Research, The University of Texas at San Antonio. Complemented by field visits, Center personnel carried out a thorough literature search and review for known historical and archaeological resources. This has resulted in an extensive bibliography and a preliminary identification and assessment of all known sites along the pipeline route. The results of the literature search, field visits and other activities of the project team are presented here. In conducting this research, Center personnel have followed the guidelines for archaeological research required by state and federal statutes and have utilized standard archaeological fieldwork procedures (cf. Hester, Heizer and Graham 1975).

Archaeological resources along the southern portion of the proposed pipeline route in Texas were examined from the proposed route center line at the Rio Grande to Station 9 at Victoria. Although all affected counties along the 214.09 mile route were archaeologically assessed, the Center's research activity concentrated on a one-mile corridor along the length of the pipeline.

The proposed pipeline route in the study area extends from a meter station in the Mexican state of Tamaulipas (across the Rio Grande) into Hidalgo County, Texas, and then northward through the counties of Brooks, Kleberg, Jim Wells, Nueces, San Patricio, Refugio, and lastly, to Station 9 in Victoria County.

Identification of previously documented sites was based on a correlation of United States Geological Survey topographic maps with published and unpublished literature, files from the Texas Archeological Research Laboratory at Austin, the Center for Archaeological Research, and various other agencies, as well as interviews with local historians and amateur archaeologists.

In addition to site identification, through both survey and file research, each archaeological locality was assigned a priority rating from 1 to 3 according to the following scale: Priority 1: a known or suspected site that will require extensive testing to determine its archaeological importance; Priority 2: a locality that suggests limited potential requiring precautionary further field testing or examination; and, Priority 3: sites requiring no further work, as recommended by field observations and/or site survey reports.

Testing activity or further research may require a variety of methods dependent upon individual site conditions, but generally will include a series of handexcavated pits using small shovels and trowels. Individual pits are not usually over $50 \mathrm{~cm}^{2}$ or $1 \mathrm{~m}^{2}$ in size. Testing operations in general determine not only the depth and frequency of cultural materials but also their relationship to natural geologic stratigraphy. All materials recovered from excavated areas are screened through $1 / 4$-inch or $1 / 8$-inch mesh to recover the largest possible sample of cultural materials. A series of test pits throughout a site enables archaeologists to assess the horizontal distribution and vertical extent of prehistoric activities in a given area. 
This page has been

redacted because it

contains restricted

information. 
Controlled surface collection, another Priority 1 or 2 activity, may also include a variety of methods, but generally follows a systematic form of sampling in which a grid or some other systematic collecting scheme is utilized at the site. Areas for total artifact collection are chosen to determine specific areas of aboriginal intra-site patterning. The ultimate goal of the recommended testing and intensive surface collection program would be to evaluate sites in terms of their potential for nomination to the National Register of Historic Places.

The archaeological sites found within the eight counties of the study area fall within four major time periods: the Paleo-Indian (ca. 9200-6000 B.C.); the Archaic (ca. 6000 B.C.-A.D. 1000); the Late Prehistoric/Neo-American (ca. A.D. 1200-1500); and the Historic (post-Eurpoean contact). Most archaeological sites in the pipeline project area are assigned to the Archaic category; these localities contain an abundance of chipped stone artifacts including stemmed and triangular dart points and specific kinds of stone tools known as Guadalupe and Clear Fork. Sites identified by earlier work include occupation sites (campsites), burned rock scatters, shell middens, chert quarries, 1ithic workshops, and temporary campsites.

Because of the extensive area covered by the pipeline route, a brief countyby-county summary of archaeological resources is presented as well as specific identifications of sites falling within a one mile corridor along the pipeline. This information, as well as site priorities, is summarized in Table 1 . Zones of high archaeological potential are identified in Table 2. Although no recorded sites are located in these limited areas (primarily due to the lack of previous research), ecological conditions such as dependable sources of fresh water and related habitats suggest attractive resources for prehistoric cultures.

\section{Hidalgo County}

Thirty-three sites have been recorded in Hidalgo County but only one is identified as a National Register site. More than half the sites in the county are the result of a survey by an amateur archaeologist in 1966. One site contains the burials of over 40 individuals and has twice been the focus of archaeological research (Hester 1969). Two other prehistoric cemeteries are located within this county (Collins, Hester and Weir 1969). Six archaeological sites are situated within one mile of the pipeline and they are listed below.

\section{Site \#}

$$
\begin{array}{llll}
A-1 & (41 & H I & 6) \\
A-2 & (41 & H I & 23) \\
A-3 & (41 & H I & 3) \\
A-4 & (41 & H I & 24) \\
A-5 & (41 & H I & 9) \\
A-6 & (41 & H I & 20)
\end{array}
$$

Priority

2

2

2

2

2

2
Milepost

31.15

39.25

39.30

39.80

40.30

40.60 
TABLE 1. ARCHAEOLOGICAL SITES PREVIOUSLY KNOWN AND RECORDED DURING SURVEY, PROPOSED PIPELINE ROUTE

(Hidalgo to Victoria Counties)

\begin{tabular}{|c|c|c|c|c|}
\hline Site Number & Priority & Description & $\begin{array}{c}\text { Milepost } \\
\text { Number }\end{array}$ & $\begin{array}{l}\text { Distance from } \\
\text { Pipeline (Miles) }\end{array}$ \\
\hline 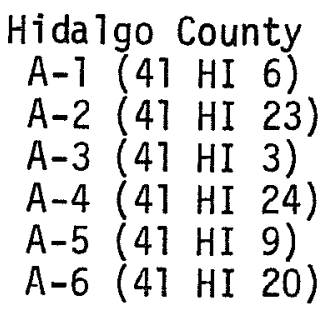 & $\begin{array}{l}2 \\
2 \\
2 \\
2 \\
2 \\
2\end{array}$ & $\begin{array}{l}\text { Cardenas Site } \\
\text { Vela Site Number } 2 \\
\text { Prehistoric Indian Site } \\
\text { Prehistoric Indian Site } \\
\text { Prehistoric Indian Site } \\
\text { Vela Site Number } 18\end{array}$ & $\begin{array}{l}31.15 \\
39.25 \\
39.30 \\
39.80 \\
40.30 \\
40.60\end{array}$ & $\begin{array}{l}.5 \\
.6 \\
.5 \\
.5 \\
.7 \\
.7\end{array}$ \\
\hline
\end{tabular}

Brooks County

$\begin{array}{lllll}\text { A-7 (41 BK 2) } & 2 & \begin{array}{l}\text { Sand Dunes Site } \\ \text { Prehistoric Lithic Scatter, }\end{array} & 80.85 \\ \text { A-8 (41 BK 3) } & 3 & \begin{array}{l}\text { Possible Occupation } \\ \text { Prehistoric Lithic Scatter, }\end{array} & .02 .80 \\ \text { A-9 (41 BK 4) } & 3 & \begin{array}{l}\text { Possible Occupation } \\ \text { Pos.27 }\end{array} & 1.0\end{array}$

Nueces County

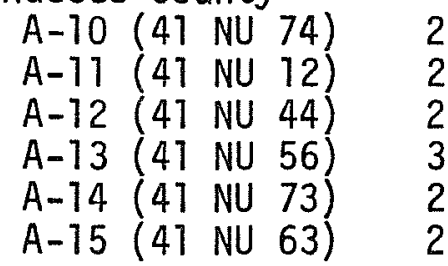

Burial

132.20

Banquete Site

132.24

Prehistoric Site

133.60

Mud Bridge Site

133.70

Possible Burial

133.70

Possible Burial

133.80

.05

.8

1.0

San Patricio County

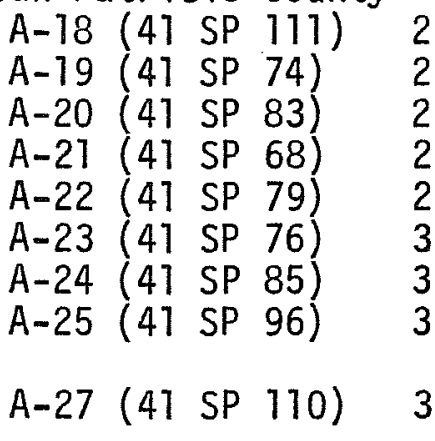

Prehistoric 0ccupation

143.95

Roadway Site

146.23

Touchstone Site

152.50

Extensive Campsite

152.90

Paleo-Indian Site

153.00

Chandler's BH 02

153.20

Light Occupation Site

155.00

.7

.2

Heavily Eroded Indian

Campsite

156.10

Prehistoric 0ccupation

Site

164.00

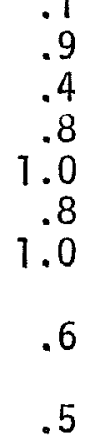

Refugio County

$\begin{array}{llll}A-36 & (41 \text { RF } & 12) & 2 \\ A-37 & (41 \text { RF } & 15) & 1\end{array}$

Sharps Lake Prehistoric

Site

Prehistoric/Early Historic

Site

194.66

intersects

197.98

1.0

Victoria County

A-32 (41 VT 64) 3

A-33 (41 VT 9) 2

A-34 (41 VT 9) 2

Prehistoric Campsite

Prehistoric Campsite

208.00

1.0

Prehistoric Campsite

208.00

.45

208.55

.9 
TABLE 2. ARCHAEOLOGICALLY SENSITIVE ZONES ALONG THE PROPOSED PIPELINE ROUTE IN TEXAS

$$
\text { (Hidalgo to Victoria Counties) }
$$

\begin{tabular}{clcc} 
Zone Number & \multicolumn{1}{c}{ Description } & $\begin{array}{c}\text { Milepost } \\
\text { Number }\end{array}$ & $\begin{array}{c}\text { Distance from } \\
\text { Pipeline (Miles) }\end{array}$ \\
\hline A-16 & Potential Lithic Procurement Area & 140.50 & .05 \\
A-17 & Nueces River & 142.60 & intersects \\
A-26 & Chiltipin Creek & 157.80 & intersects \\
A-28 & Aransas River & 164.80 & intersects \\
A-29 & Medio Creek & 179.14 & intersects \\
A-30 & Blanco Creek & 179.40 & intersects \\
A-31 & San Antonio River & 199.98 & intersects \\
A-35 & Guadalupe River & 211.28 & intersects
\end{tabular}


Brooks County

Presently, only five sites are recorded for Brooks County and none are listed on the National Register of Historic Places. The first sites located in the county were discovered by an amateur working in the area and by $A$. T. Jackson with The University of Texas in 1932. Three recorded sites are located within one mile of the pipe and they are listed below.

\begin{tabular}{ccc} 
Site \# & Priority & Milepost \\
\cline { 2 - 3 }$A-7(41$ BK 2$)$ & 2 & 80.85 \\
A-8 (41 BK 3) & 1 & 82.7 \\
A-9 (41 BK 4) & 3 & 83.27
\end{tabular}

Jim wells County

Only scattered archaeological reconnaissance has been conducted in Jim Wells County and eight sites are on file, six of which have been recorded since 1967 (Hester and Bass 1975; Patterson 1974). A professional, limited excavation of $41 \mathrm{JW} 8$ has been conducted by the Center (Hester 1977). No recorded archaeological sites are located within one mile of the pipeline corridor.

\section{Kleberg County}

Seventy archaeological sites are presentiy on record for Kleberg County including two National Register sites. The county has been the focus of four professional archaeological surveys, the first of which was conducted by G. Arnold (unpublishted notes) and The University of Texas. In 1964, a survey of a portion of Padre Island added 12 sites to the county file and in 1967, 12 more sites were located during a survey near Baffin Bay (Briggs 1971). The latest professional work was done by Hester $(1969,1971)$ during which 40 prehistoric sites were identified in the vicinity of the Cayo Del Grullo. Hester (1973) has also reported site $41 \mathrm{KL} 54$. No recorded archaeological sites are located within one mile of the proposed pipeline.

\section{Nueces County}

A total of 156 archaeological sites has been recorded for Nueces County but only one is a National Register site. Amateur surveys by members of the Coastal Bend Archaeological Society (Corpus Christi) have resulted in the location of almost one-fourth of the total sites. A professional survey of Padre Island by Campbel1 (1964) has located three sites within Nueces County (see also Scurlock et al. 1974). Other professional surveys have led to the documentation of 34 sites along 0so Creek, 47 sites along Petronila Creek, and 46 other prehistoric sites within the Oso Creek Floodwater Control Project area (Patterson and Ford 1974). Several sites have been tested or excavated, including two sites on the Callo de 0so (Martin 1930). Woolsey, working with The University of Texas, tested two sites in 1936, and Campbe11 (1956) reported Nueces County 
sites in the Laguna Madre (see additional discussion in Briggs 1971). Six archaeological sites are located within one mile of the pipeline in Nueces County and they are listed below.

Site \#

$A-10(41 \mathrm{NU} 74)$

A-11 (41 NU 12)

$A-12(41$ NU 44)

$A-13(47$ NU 56)

A-14 (41 NU 73)

A-15 (41 NU 63)
Priority

2

2

2

1

2

Milepost

132.20

132.24

133.60

133.70

133.70

133.80

\section{San Patricio County}

Professional and amateur surveys have recorded most of the 116 sites presently known in San Patricio County. Sixteen prehistoric sites were located in the vicinity of Corpus Christi Bay by Corbin (1963; see also Story 1968) and later, 18 sites were recorded by Holliday and Grombacher (1973) along Chiltipin Creek. Most other sites were discovered by members of the Coastal Bend Archaeological Society. Martin and Potter (n.d.) also worked in this region from 1927-29. The only resource on the National Register of Historic Places is located outside of the pipeline study area. Nine recorded sites are located within one mile of the pipeline and they are listed below.

Site \#

$\begin{array}{llll}A-18 & (41 & S P & 111) \\ A-19 & (41 & S P & 74) \\ A-20 & (41 & S P & 83) \\ A-21 & (41 & S P & 68) \\ A-22 & (41 & S P & 79) \\ A-23 & (41 & S P & 76) \\ A-24 & (41 & S P & 85) \\ A-25 & (41 & S P & 96) \\ A-27 & (41 & S P & 110)\end{array}$

Priority

2

2

2

2

2

1

1

1
Milepost

143.95

146.23

152.50

152.90

153.00

153.20

155.00

156.10

164.00

\section{Refugio County}

At present, 18 archaeological sites are recorded for the county. An archaeological survey by Martin and Potter (n.d.) in 1927-29 located five sites, and the rest have been discovered since the 1960s. No testing or excavations have been conducted in this county. Two recorded archaeological sites are located within one mile of the pipeline, and several archaeologically sensitive zones are identified in Table 2 (A-28 thru A-32). 


\section{Site \#}

A-36 (41 RF 12)

A-37 (41 RF 15)
Priority

2

1
Milepost

194.66

197.98

\section{Victoria County}

To date, 59 prehistoric sites have been recorded for the county, including many open campsites and burials. Only one professional survey has been conducted (Fox and Hester 1976), along portions of Coleto Creek. Useful site surveys have also been conducted by local amateur archaeologists. Three professionally-run excavations have taken place: in 1938-40, The University of Texas excavated the Morhiss Site (41 VT 1; Campbe11 1962; and in Fox and Hester 1976); the Texas Memorial Museum tested the proposed site of LaSalle's Fort St. Louis on Garcitas Creek in 1950 and 1967 (Gilmore 1973); and the Texas Archeological Society carried out testing of the proposed second site of the Presidio Loreto north of Victoria. The Victoria Archaeological Society has also carried out a number of test excavations at local sites. There have been two submissions to the National Register of Historic Places. These are Fort St. Louis and 47 VT 76 (Willeke Site), both outside the study area. Three recorded archaeological sites are located within one mile of the pipeline corridor and they are listed below.

Site \#

A-32 (41 VT 64)

$A-33(41$ VT 9$)$

A-34 (41 VT 9)
Priority

3

2

2
Milepost

208.00

208.00

208.55 


\section{RESULTS OF FIELD INSPECTION OF PIPELINE ROUTE}

Thomas C. Kel1y

Limited field inspection of the pipeline route was performed by Thomas $C$. Kelly, Research Associate, UTSA, often assisted by the Tenneco people listed in the Acknowledgment section.

\section{Objective}

The primary objective of the field inspection was to locate critical areas containing cultural resources (historical and archaeological sites) that might affect the pipeline route. Part of our contract was also to provide the necessary field data to make recommendations, if necessary, for alternate pipeline routes.

\section{Procedure}

High potential areas were marked for survey from a detailed map study before the first field trip. These were mostly ridges and stream crossings within one mile of the pipeline centerline. Previously recorded sites on record at the Texas Archeological Research Laboratory at Aust in were plotted along the route to provide further guidance. The areas were reached by pickup and examined on foot. A11 open areas, such as ant beds, unimproved road tracks, and eroding ridges or gulleys, were carefully inspected. When sites were found, they were recorded on standard Center for Archaeological Research site survey forms, photographed, and a representative sample was collected for laboratory analysis.

A Tenneco helicopter was utilized for two days to check the pipeline and adjacent areas from District 9 at Victoria to the Mexican border east of McAllen. This was the first such use of aerial survey by the Center for Archaeological Research. The 214 miles of pipeline were covered from altitudes of from 1 to 50 feet, with one-mile excursions either side of the pipeline at every creek and river crossing. Four of the eight prehistoric sites, and all four of the potential historic sites, were originally located and photographed from the helicopter.

Possibly the greatest value of the helicopter in this particular survey was to better evaluate numerous and extensive areas of low site discovery potential. Such areas exist where there is very dense ground cover; or, as in the Rio Grande flood plain, where man has extensively altered the surface by intensive irrigation, cultivation and citrus groves. The first 81 pipeline miles were so inspected, and it was predicted that few cultural resources would be found. To check the efficacy of the aerial survey, a 26-mile stretch between Mile 39.7 (FM 1017) and Mile 66 (Encino) was later walked out. The net results of the long walk were three isolated flakes and a heatstroke. Thus, the helicopter would seem to be a great aid in large scale archaeological surveys, especially in open areas, if the expense factor can be accomrnodated. 


\section{Bias Factor}

The entire survey was severely handicapped by unusually dense ground cover of grass and brush resulting from a wet spring. Heavy rains from Hurricane Anita further complicated inspection of portions of the route. Twenty-five days of field work produced eight new archaeological sites, a very low number for a region that, in certain areas, has abundant archaeological resources. Even so, the two new sites in Brooks County doubled the previously reported sites!

Field Inspection Results

Pipeline Milepost

0 The Tenneco pipeline beginning at the Rio Grande snakes through many small, intensively cultivated, flat tracts of farm land and citrus groves. The route is difficult to follow from the air

27 because all the surface has been altered since the pipeline was built. It straightens out at mile 27 (near plant 409) but continues through very flat cultivated land and small pastures to

41.50 mile 41.50 north of Linn, Texas. The archaeological potential to this point appears to be practically nil. Fig. 2 (MP 41, looking south) shows this dividing line at the edge of the Rio Grande flood plain.*

The land north is apparently unaltered King Ranch rangeland (Fig. 3, MP 63) which is flat with very low sandy hills that must blow and drift during drought periods. Three days were spent walking from MP 39.7 at Linn to MP 66 at Encino just to verify the observation made from the helicopter that the area had very low archaeological potential. Not a single archaeological site was found.

51.40 A potential historical site was found by helicopter and photographed (Fig. 4). It consisted of tumbled bricks at the edge of a smal1 depression and is possibly associated with the Southern Pacific Railroad. The site was not ground-checked because of a heatstroke that incapacitated the surveyor. Survey and a literary search are

66 recommended.

There are no perceptible changes in terrain until MP 82. There are no creeks, streams or natural lakes, and this country was not successfully opened for cattle grazing until the advent of the windmi11. It is possible that prehistoric people largely avoided the area, a theory that needs confirmation by field examination.

82 The archaeological potential becomes greater because of Baluarte and Palo Blanco Creeks, and the Laguna Salada into which they empty, east of the pipeline.

82.70 A Late Prehistoric site (Tenneco A-8; 41 BK 3) was found from the helicopter on a ridge overlooking the Laguna Salada between the two

*MP: Milepost, on pipeline route. 


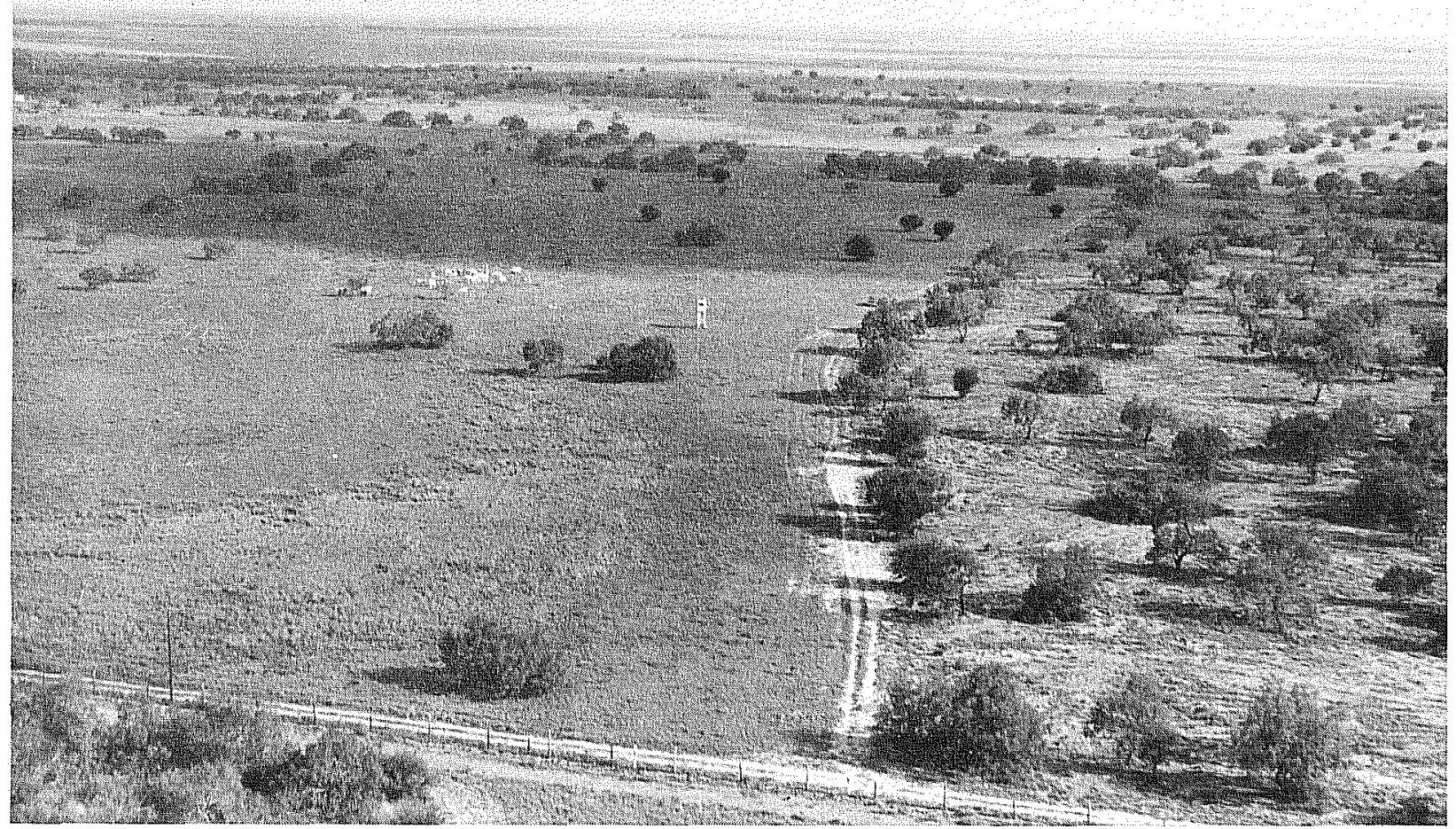

Figure 2. Tenneco MP 41, Looking South. Tennessee Gas Pipeline Right-ofWay, beginning of Rio Grande floodplain, Hidalgo County. Helicopter view.

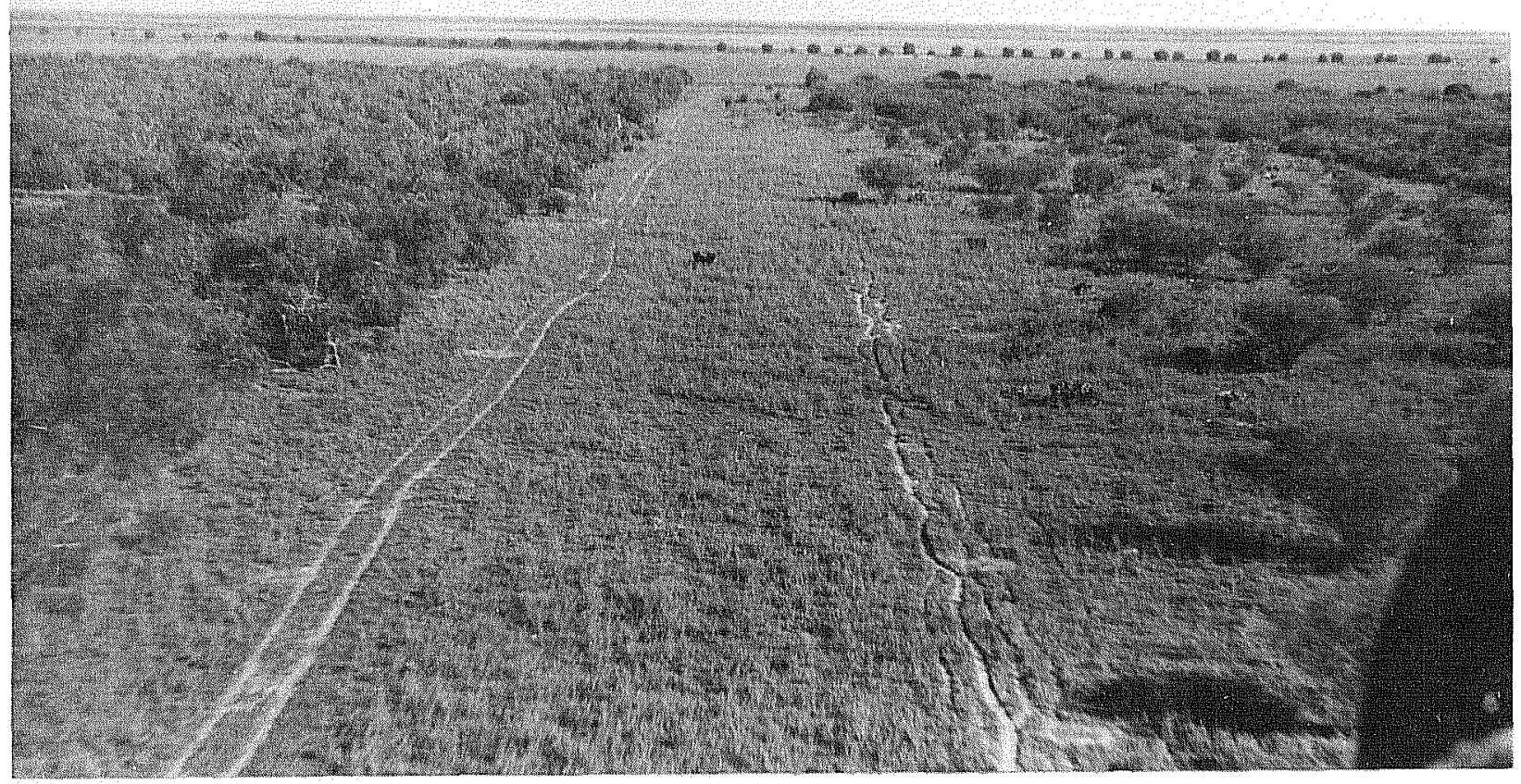

Figure 3. Tenneco MP 63. Typical view of Tennessee Gas Pipeline Right-of Way, King Ranch, Hidalgo County. Helicopter view. 


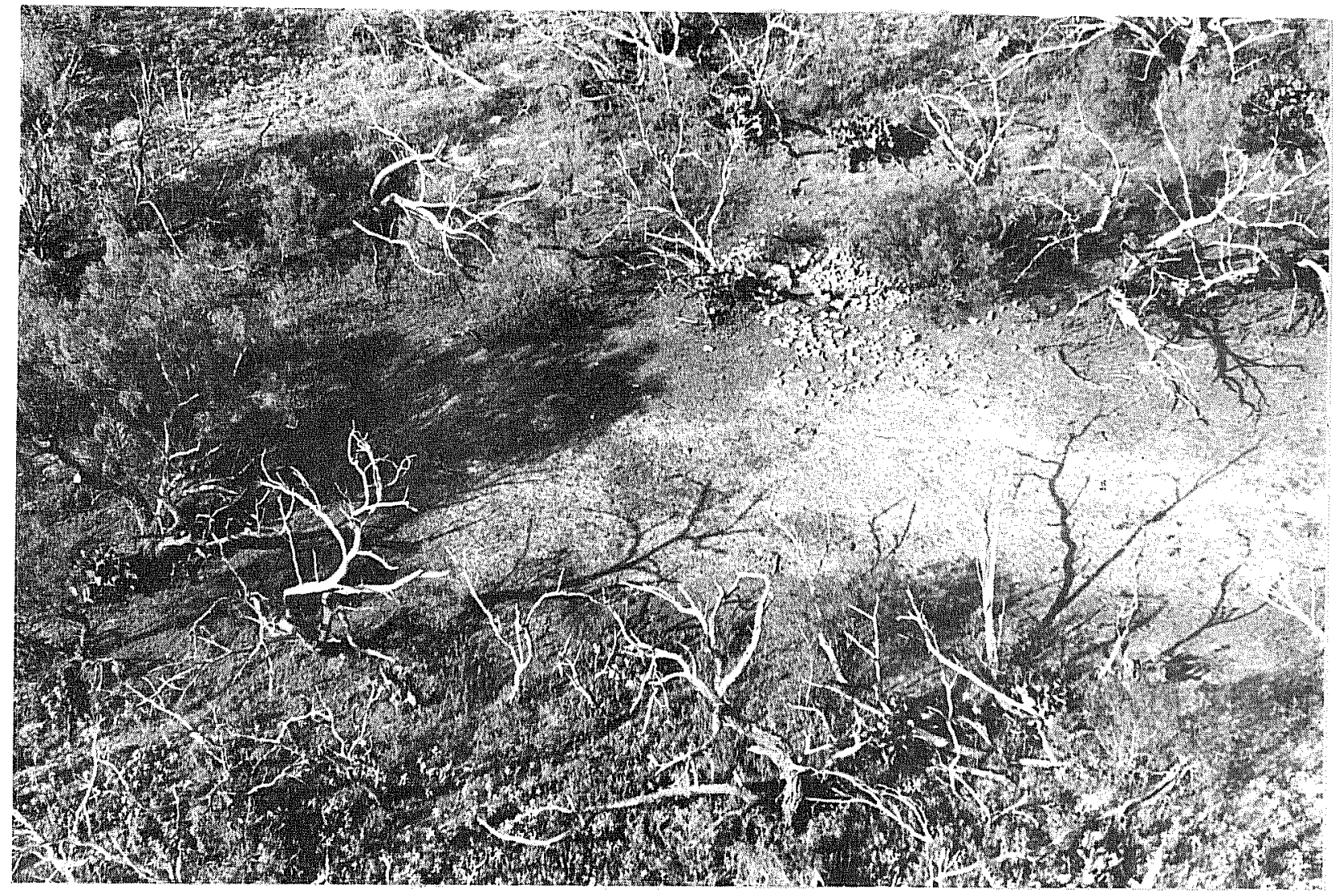

Figure 4. Tenneco MP 51.4. Potential historic site, possibly associated with Southern Pacific Railroad (Site H-17). Hidalgo County. Helicopter view.

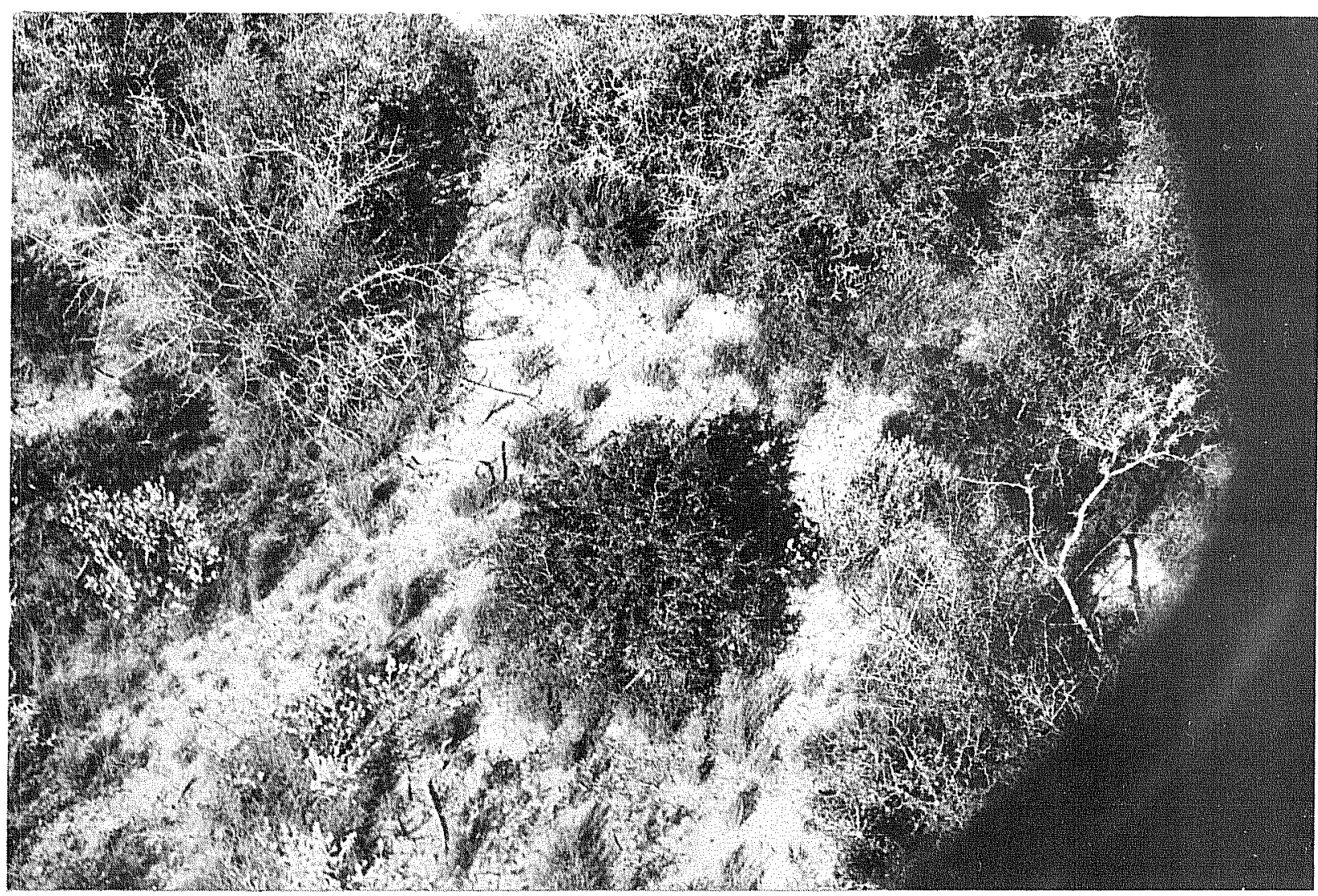

Figure 5. Tenneco MP 82.70 Laguna Salada. Site A-8 (41 BK 3); one of the few openings along the 600-meter ridge. Helicopter view. 


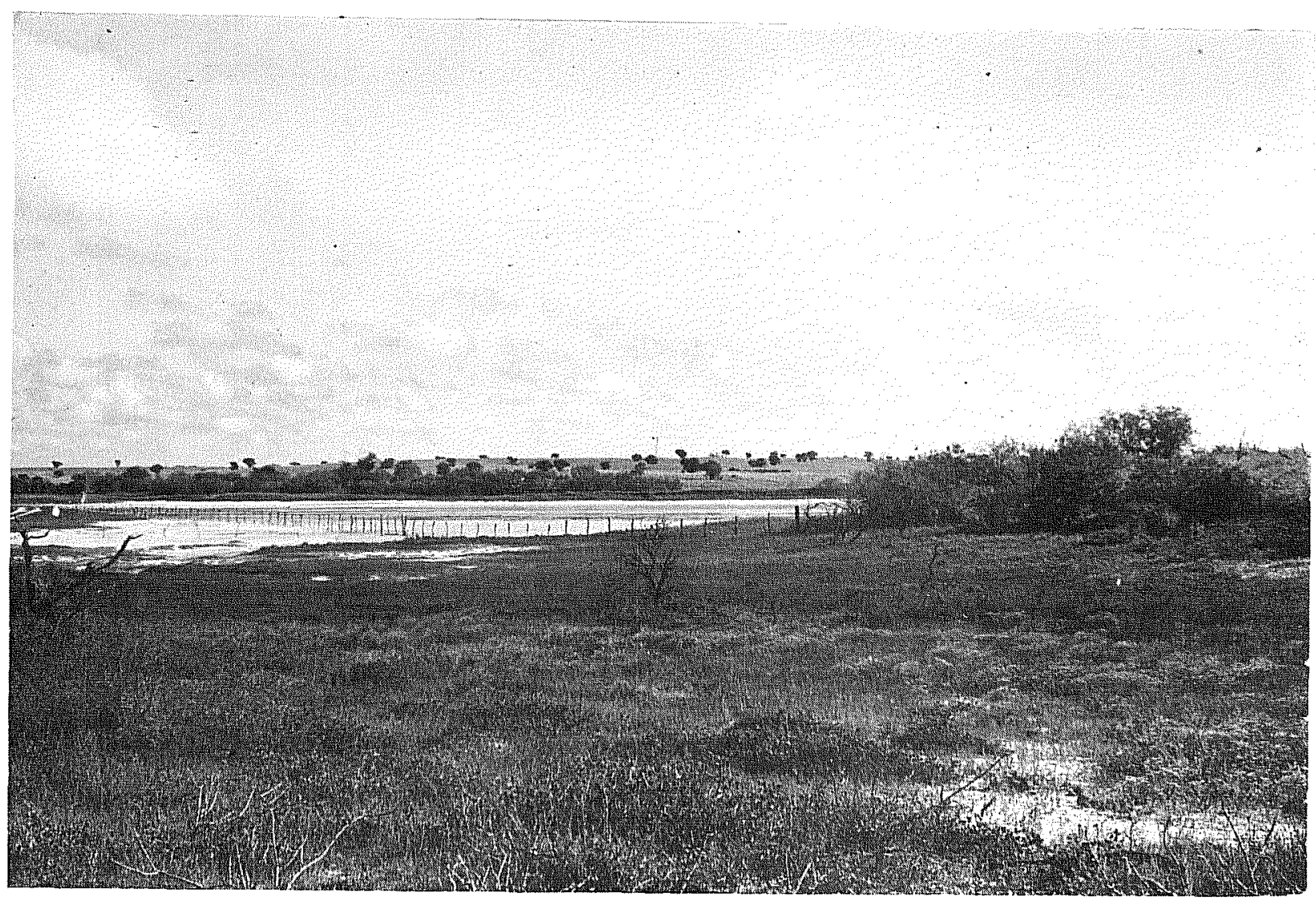

Figure 8. Tenneco MP 83.27. Site A-9 (41 BK 4) is on ridge across Laguna Salada; looking northeast. Brooks County.

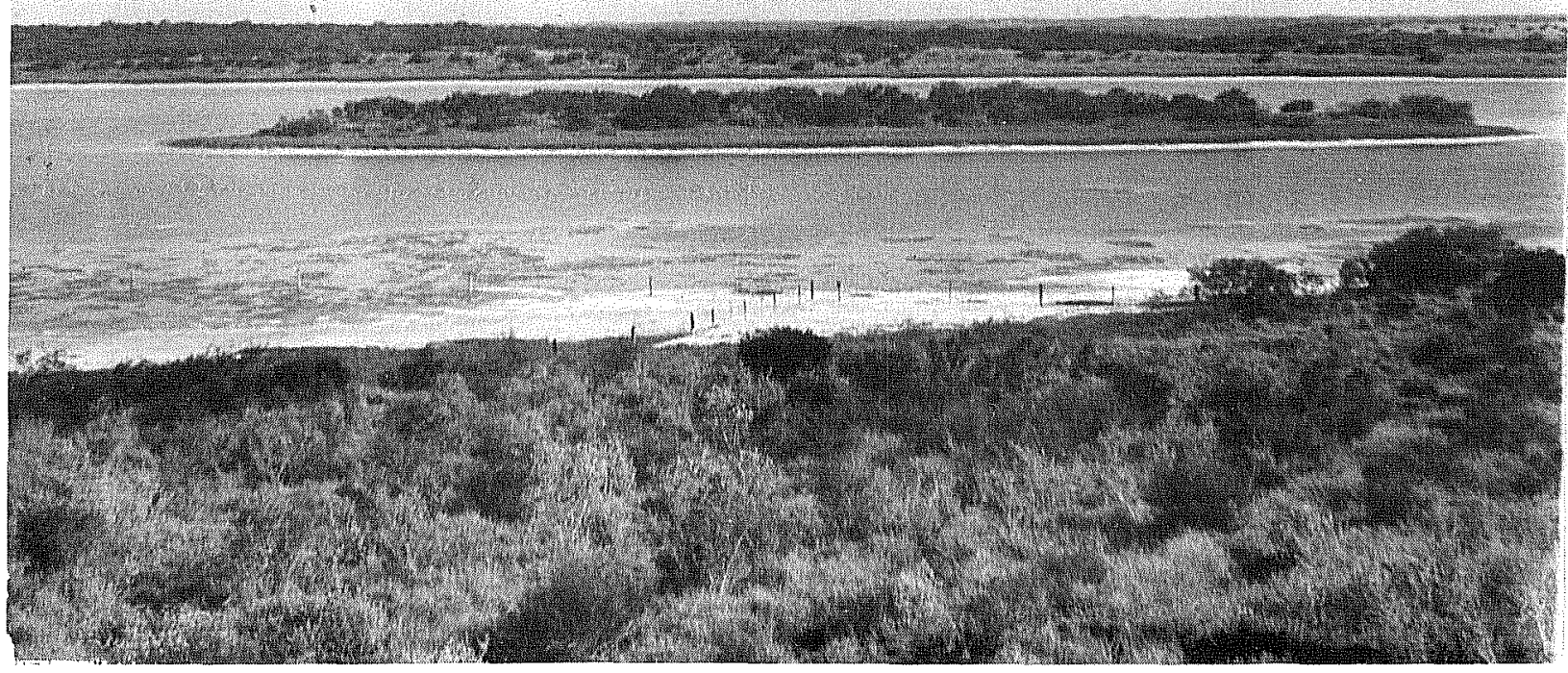

Figure 9. Potential Archaeological Site. Island in Laguna Salada. Brooks County. 


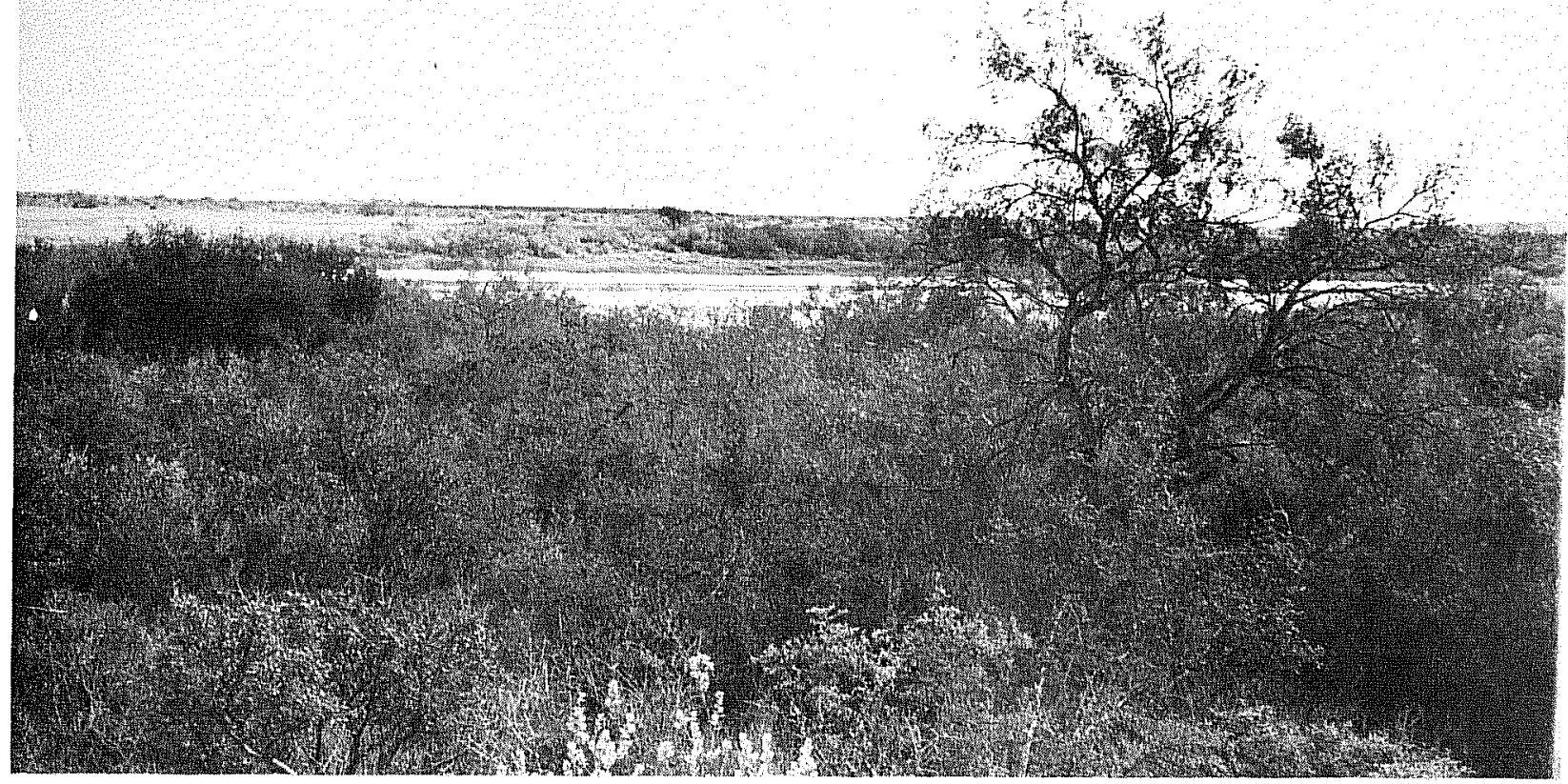

Figure 6. Tenneco MP 82.70. Site A-8 (41 BK 3); Laguna Salada, looking north across Palo Blanco section (helicopter view). Brooks County.

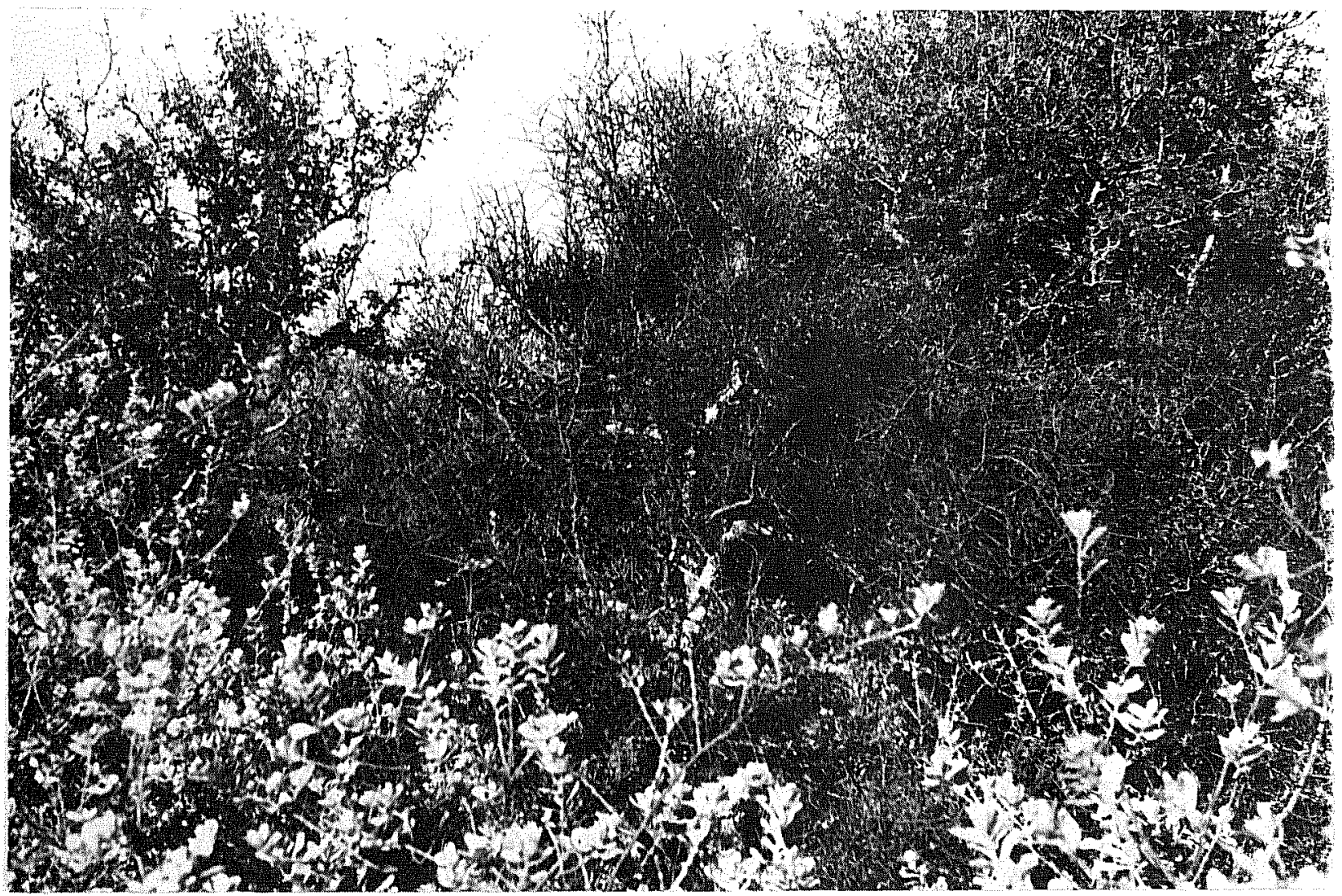

Figure 7. Tenneco MP 82.70. Typical Brooks County vegetation, vicinity of Site A-8 (41 BK 3), Laguna Salada; helicopter view. 
creeks. Snail shells were observed in one of the openings along the ridge (Fig. 5). Fig. 6 illustrates the dense vegetation and overlook view of the north arm of the Laguna from the ridge. A day was later spent in walking as much of the ridge as was possible, in which the surveyor was greatly assisted by Mr. Jim Gault from Station 9. The dense brush (Fig. 7) permitted only a limited look at the ridge, but chert flakes, bifaces, finely-made end-of-blade scrapers, plainware pottery, shell and snails were collected.

83 The entire area between MP 81 and 83, including the smal1 Laguna Salada west of the pipeline, is recommended for intensive survey as a potentially important archaeological zone.

83.27 The north side of the Laguna Salada was surveyed on foot (aga in with the assistance of Mr. Gault) and another Late Prehistoric site (Tenneco A-9; 41 BK 4) was found exposed by a road on the western part of the ridge overlooking the north shore of the Laguna (Fig. 8). A projectile point, a finely-made end-of-blade scraper and flakes were found over an approximate 10 meter area. Extremely dense buffalo grass to the east probably obscures other sites. It is also probable that a series of small sites could be found around the Laguna.

82.50 An island photographed from the helicopter (Fig. 9) in the Laguna Salada is a potential archaeological site and is recommended for survey.

92 Paisano Creek was covered with heavy vegetation and the banks were too poorly defined to warrant more than a cursory walk, and nothing was found.

103.50 Derramadero de Machos Creek was so poorly defined and hidden that it could not be seen from the helicopter. It has not yet been checked on foot.

87.40 Escondido Creek and Los 01mos Creeks have archaeological potential 106 and it is recommended that they be surveyed at a time of less vegetational cover.

132.40 Agua Dulce Creek near the pipeline is a veritable jungle and swamp (Fig. 10) and was impossible to survey on foot. Upstream, 4.4 miles to the northwest, is the historic marker commemorating the deaths of a group of Texans at the hands of General Jose Urrea on March 2, 1836. A mile of the creek on each side of the pipeline crossing was surveyed, and traces of prehistoric activity were found only on the west side. No further action is recommended until brush is cleared along the pipeline at the Agua Dulce Creek crossing.

133.95 Banquete Creek has high archaeological potential as sites have been previously reported along it. Brush and grass were too heavy to permit survey. We recommend an intensive survey. 


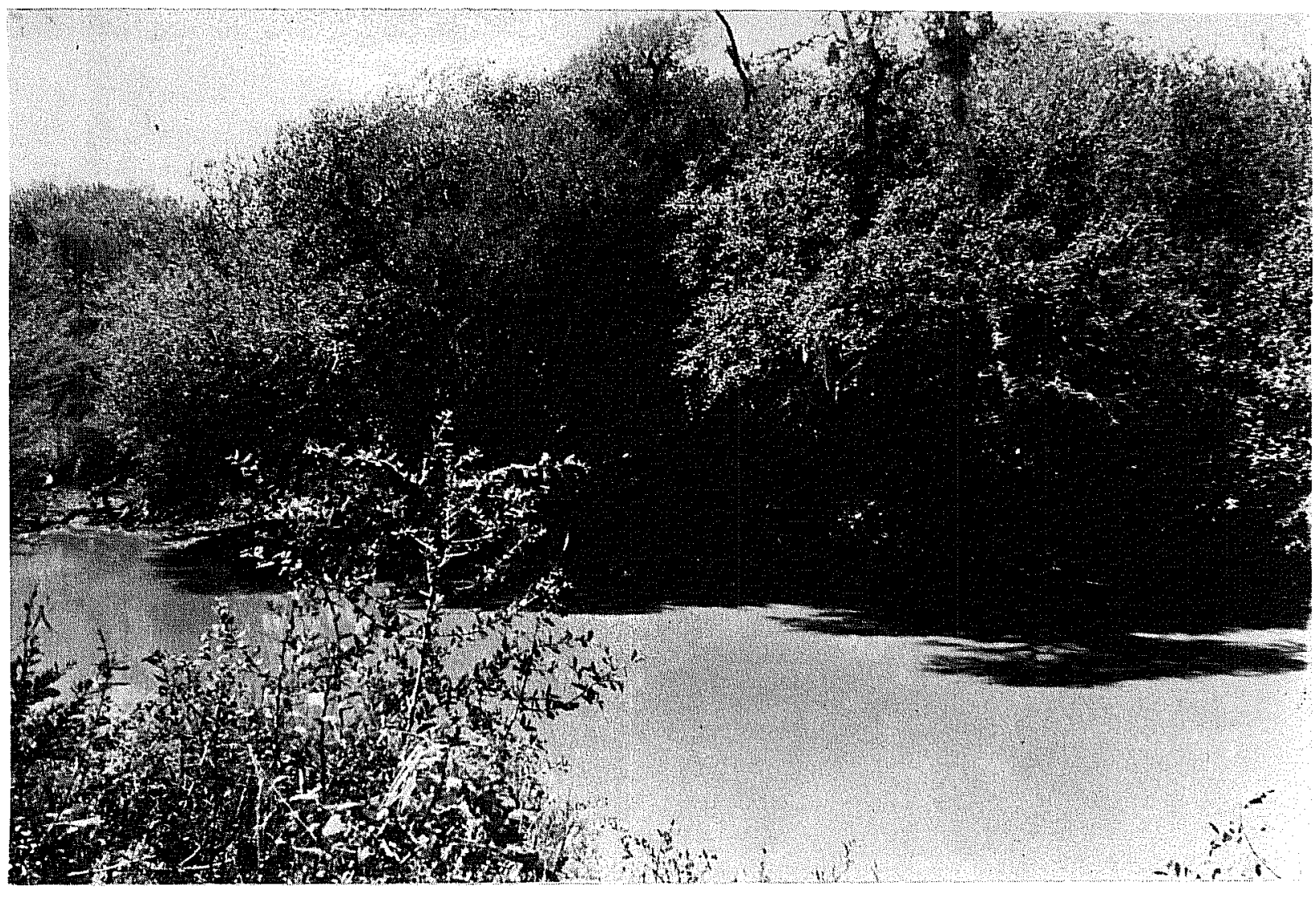

Figure 10. Tenneco MP 132.4. Agua Dulce Creek; helicopter view. Nueces County.

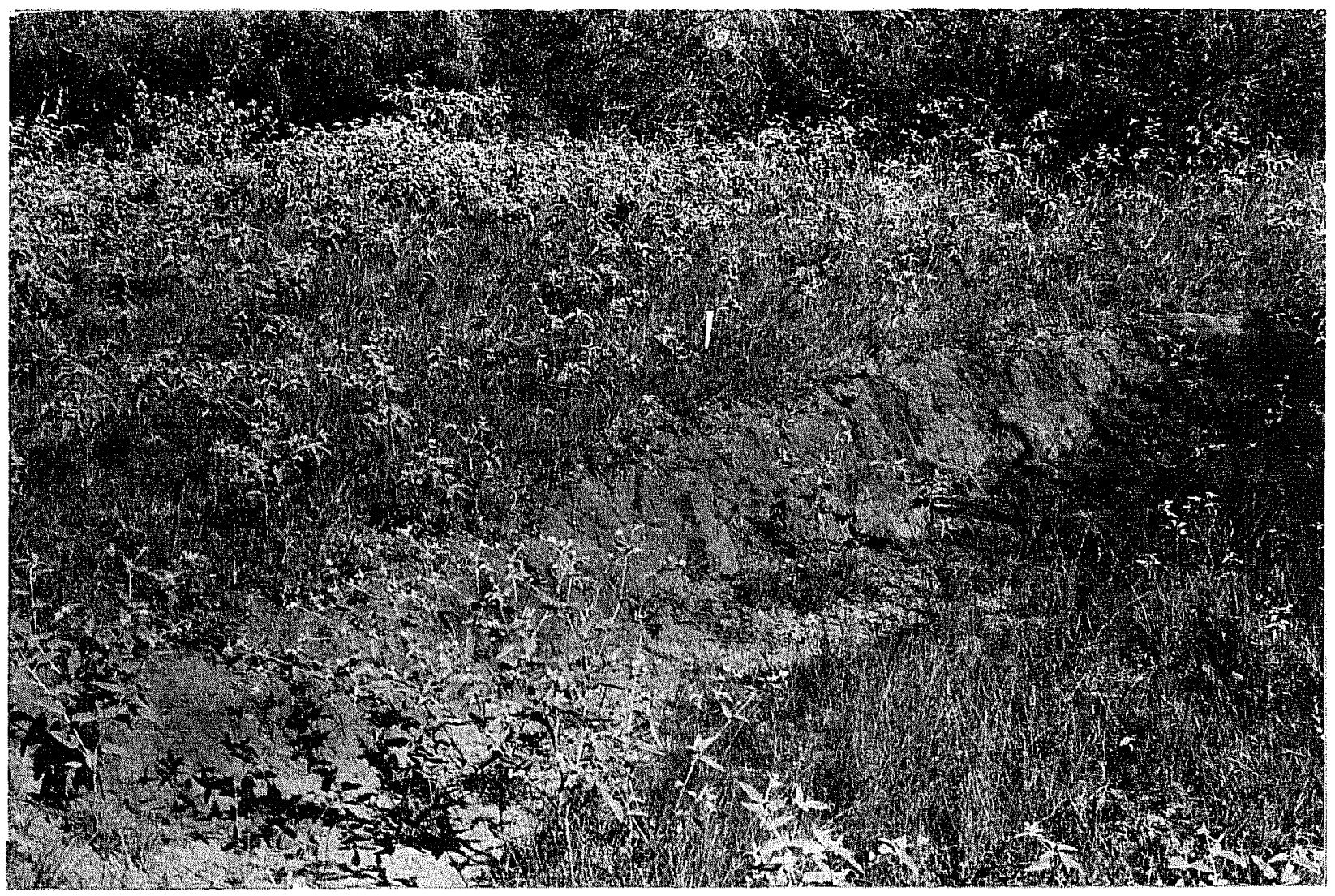

Figure 11. North Bank of Nueces River. View of Zone A-17; helicopter view. San Patricio County. MP 142.60 
140.50 The ridges on the south bank of the Nueces River and the grave quarries closer to the river appear from the air to be potential archaeological zones and are recommended for intensive survey.

142.60 Zone of potential archaeological significance, designated A-17 (Figs. 11, 12), was found on the north bank of the Nueces River.

143 A potential site was located by helicopter on the ridge north of the Nueces River one mile west of the pipeiline (Fig. 13), and we recommend an intensive survey.

143.95 Tenneco A-18 (41 SP 111) is a smal1 eroding site in the bank of a sandy gully in the east edge of the right-of-way. Not enough material was recovered to identify the time period of occupation. Intensive survey and limited testing are recommended in this area. The Nueces River was flown almost at water level for five miles either side of the route, and, as is common with the other rivers, no sites were seen on the river banks of the present stream.

153.54 Chiltipin Creek is another high potential archaeological area based on previously reported sites. One is reported on either side of the pipeline, and considerable effort was made to either find the old sites or new ones without any result other than one exhausted core and a chert flake. We recommend intensive survey in time of less brush cover.

164.00 Tenneco A-27 (41 SP 110) is a prehistoric site consisting of a sma11 mussel shell concentration eroding near the top of the steep west upland bank of the Aransas River. A biface and a few chert flakes were associated with the deposit, but not enough material was found to identify the time period. Four miles of walking in the river bottom produced absolutely nothing. The west ridge north of the pipeline should be a high potential area, and further survey along the ridge and its eroding banks is recommended.

167 Sous Creek has both cultivated fields and shallow banks overgrown with vegetation. A three-mile walk from Highway 77 to the pipeline provided no evidence of any ancient inhabitants. The creek appears to have no archaeological potential.

167 The pipeline was walked from mile 167 to 168 and Devil's Run Creek three miles back to Highway 77 with no archaeological evidence found.

179.14 Medio Creek had reasonable ground visibility, but if there are any sites in the vicinity of the pipeline, they are buried under the loose sand in the area.

179.40 Blanco Creek should also have been a potential archaeological area as well as the area where the two creeks join, but no archaeological evidence was found in about four miles of walking. 


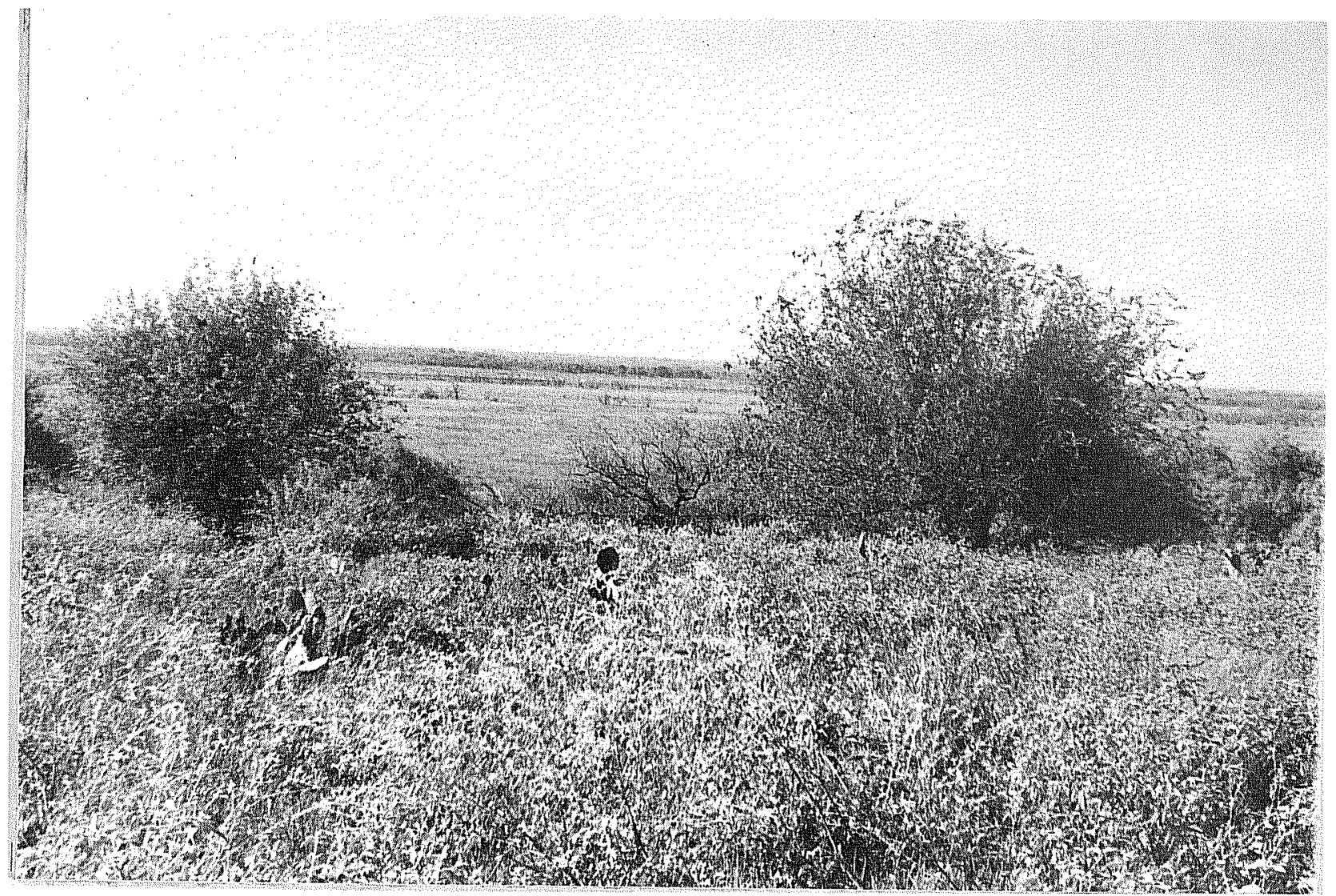

Figure 12. View of Zone A-17. Looking west across floodplain to Nueces River; San Patricio County. MP 142.60

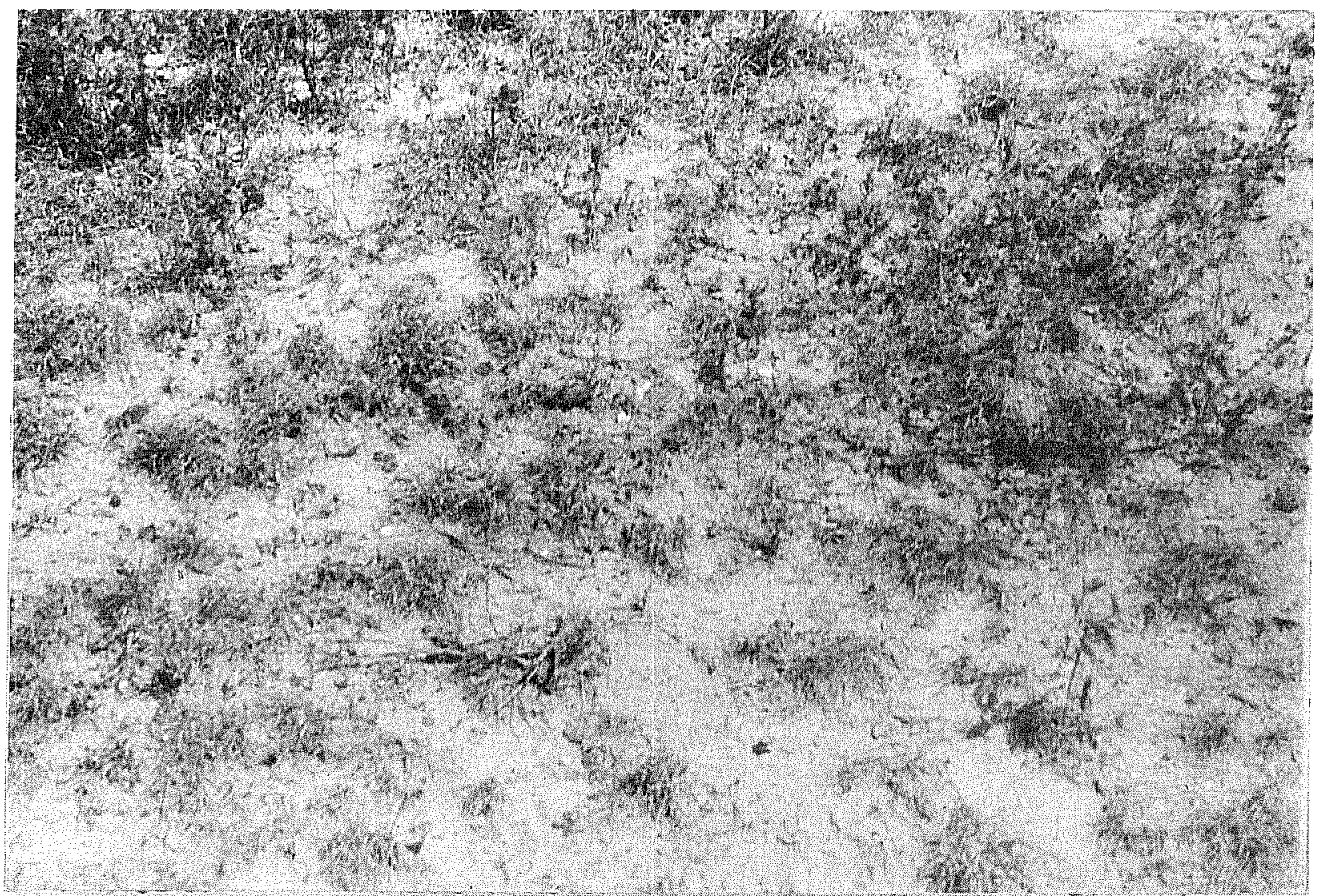

Figure 13. Tenneco MP 143. Potential archaeological site. Ridgeline of Nueces River, one mile west of Tennessee Gas Pipeline. Helicopter view; 
186.36 Melon Creek has plenty of open, eroding areas, but only two pieces of chert were found in a two-mile search on either side of the pipe1ine. No further action is recommended in this area.

189.5 A wooden cabin with a large brick chimney was observed from the helicopter in the south side of the route. We recommend investigation as a potential historical site, possibly a line cabin.

194.66 Tenneco A-36 (41 RF 12) is a prehistoric knapping station and campsite with possible burials. It is in the route and consists (at the time of the field visit) of scattered chert over a 50 meter area. Unfortunately, no diagnostic artifacts were recovered. Men at Tenneco Station 9 recal1 digging up human bones while repairing a leak in that area about 1948. Sharps Lake was a prehistoric water source and one of the localities picked from map study as having high potential. An intensive survey and testing is recommended for this site.

197.98 Tenneco A-37 (41 RF 15) is an archaeological site with both prehistoric and late 19th century historic material. It is exposed by a ranch road on a sandy ridge that was a former south bank of the San Antonio River, now two miles south of the present river course. Over 15 meters of the road contain chert and historic material, undoubtedly derived from higher up on the ridge. The ridge was in dense feed grain and could not be explored. The John White Bower historical monument is located on the same ridge approximately 450 meters northwest. This ridge was walked from $41 \mathrm{RF} 15$ to the pipeline, but the ground cover was too heavy for careful examination. We recommend intensive survey of this area when there is no grass or feed grain.

199.98 A two-story frame house with gingerbread trim was located and photographed from the helicopter as a potential historical site. It is the old Urban family home and, though weatherbeaten, appears to be in good shape. The garbage dump southwest of the house is still being used by someone and is being covered up periodically by bul1dozer. There is a possibility that early refuse is thus preserved. We recommend an on-site inspection and records search (Tenneco $A-37$; see Table 2).

200.34 The tumbled chimney of the De La Garza (?) homestead is visible at 0.1 mile southeast of the pipeline. We recommend intensive survey of this potential historic site after proper contact is made with the landowner.

200.72 The De La Garza cemetery is in the south edge of the route.

208 Tenneco A-32 (41 VT 64) is a multipurpose prehistoric campsite 0.45 miles northwest of the pipeline on a high ridge overlooking the west Guadalupe River flood plain, two miles west of the present course of 
the river. The site is exposed, in a bulldozed farm road, over a 10 meter area. Not enough material was recovered to establish the time period of the site. The ridge is a potential archaeological zone and should be intensively surveyed under conditions of less grass cover.

208 Tenneco A-33, A-34 (41 VT 9) is a multipurpose Late Prehistoric campsite located southeast of the pipeline. Tenneco A-33 is on a hill overlooking McDonald Bayou; Tenneco A-34 adjoins A-33 northeast of the hill in a marshy area where two swamp roads intersect. Flakes, bifaces and a finely made end-of-blade scraper were found associated with snail shells, turtle carapace and a few bones. These ridges west of the Guadalupe River are certainly high potential archaeological zones and it is recommended that an intensive survey be conducted at a better period of ground visibility.

211.28 The Guadalupe River flood plain was checked out on both sides of the river, involving approximately five miles of often difficult walking. Nothing was found, but there are beautiful natural sections in the sheer banks of the river that record one flood deposition on top of another. Any prehistoric sites that were located on the river banks would be deeply buried. The only hope for finding sites would seem to be in these steep sections of the area in which erosion is taking place (Tenneco A-35; see Table 2).

212.3 The east ridge was walked wherever possible, but the Victoria Barge Canal, Turning Basin and a series of commercial gravel and sand quarries have effectively spoiled any possible chance of finding archaeological sites. These pits contain Uvalde Gravels which are probably the source of the prehistoric chert industry in the area.

Our recommendations are summarized in Tables 1 and 2.

\section{Illustrations of Selected Artifacts}

During the course of the preliminary survey, a few artifacts were collected. In general, however, no extensive artifact collections were made. A selection of specimens found at sites along or near the pipeline route is shown in Fig. 14 . 

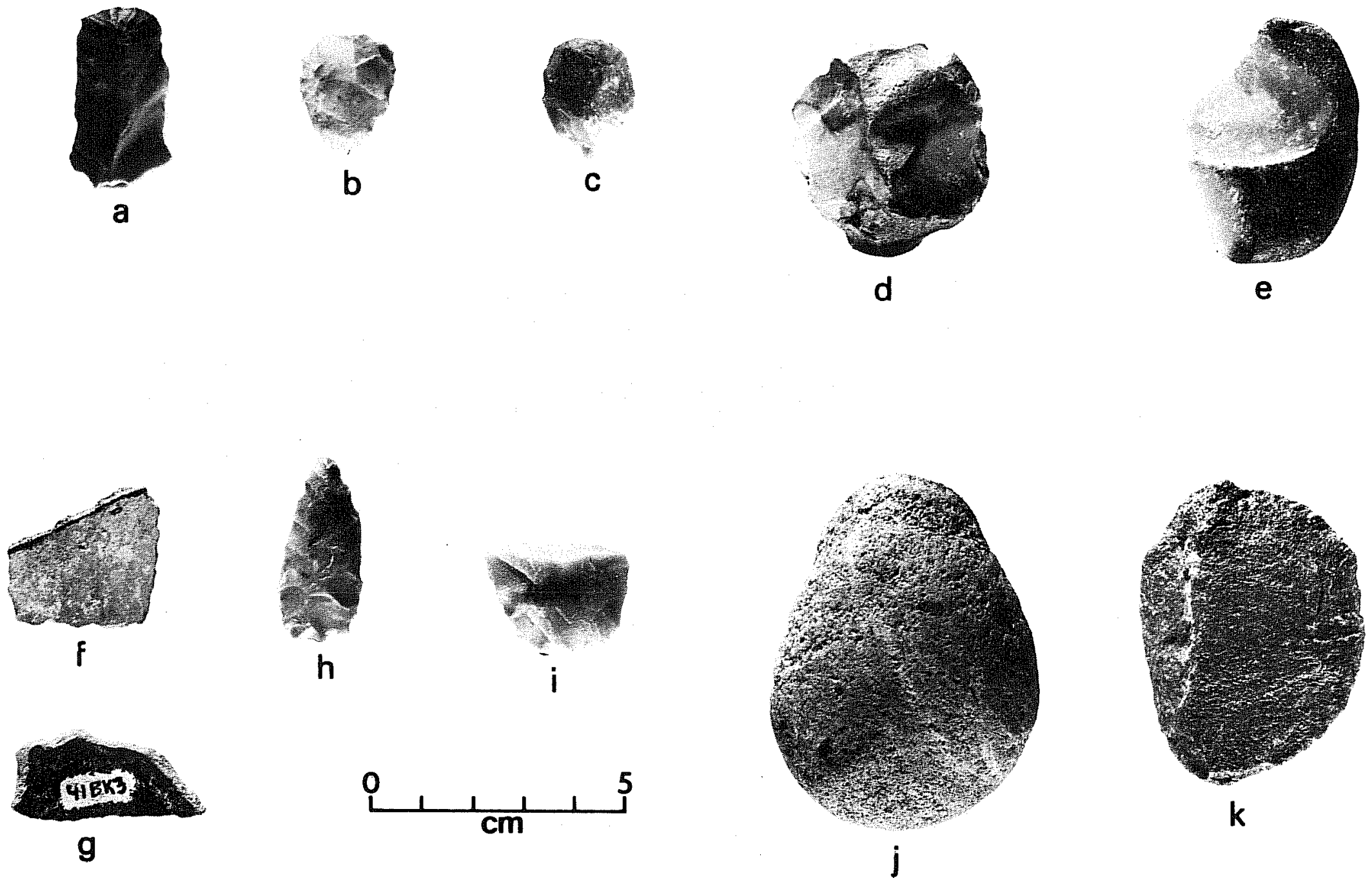

g

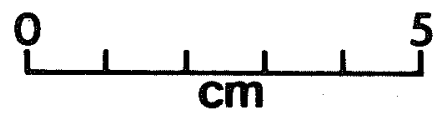

j

Figure 14. Selected Artifacts. a, 41 VT 9, end scraper; b-c, 41 BK 3, scrapers (c, end scraper); d-e, 41 BK 3, exhausted cores; $f-g, 41$ BK 3 , bone-tempered potsherds; $h, 41$ BK 3 , arrow point preform; $i$, 41 BK 3, biface fragment; $j, 41$ VT 9, quartzite hammerstone; k, 41 RF 12, quartzite hammerstone. 
III. RESEARCH BIBLIOGRAPHY: PREHISTORIC AND HISTORIC ABORIGINAL CULTURES

Fred Valdez, Jr.

Abbreviations Used

BTAS (BTAPS) Bulletin of the Texas Archeological Society (formerly Texas

Archeological and Paleontological Society)

N-HAS Newsletter, Houston Archeological Society

TA Texas Archeology (Newsletter, Texas Archeological Society)

TJS Texas Journal of Science

UTSA-CAR University of Texas at San Antonio, Center for Archaeological Research

-ASR Archaeological Survey Report

-SR Special Report

Anderson, A. E.

1932 Artifacts of the Rio Grande Delta Region. BTAPS 4:29-31.

Anonymous

1975 Coleto Creek Project. Informational pamphlet issued by GuadalupeBlanco River Authority and Central Light and Power Company. On file at Center for Archaeological Research, The University of Texas at San Antonio.

Aten, L. E.

1968 Geologic Approaches to Archeological Problems Along the Northern Coast of the Gulf of Mexico. Paper delivered at AAAS meeting, Symposium on Environment and Prehistory from Woodlands to Desert. Dallas, Texas.

Berlandier, J. L.

1969 The Indians of Texas in 1830. Edited by John C. Ewers. Smithsonian Institution Press, Washington.

Birmingham, W. W. and T. R. Hester

1976

Late Pleistocene Archaeological Remains at the Johnston-Heller Site, Texas Coastal Plain. In: Papers on Paleo-Indian Archaeology in Texas: 1. UTSA-CAR-SR 3:15-33. 
Breuer, J. P.

1957 An Ecological Survey of Baffin and A7azan Bays, Texas. Publications of the Institute of Marine Science, University of Texas $4(2): 134-155$.

Briggs, A. K.

1971 Archeological Resources in the Texas Coastal Lowlands and Littoral. Texas Historical Survey Committee and Texas Water Development Board.

Brown, L. F., Jr., W. L. Fisher, A. W. Erxleban and J. H. McGowen

1971 Resource Capability Units--Their Utility in Land and Water-Use Management with Examples from the Texas Coastal Zone. University of Texas at Austin, Bureau of Economic Geology, Geological Circular 71-1, $22 \mathrm{pp}$.

Calhoun, C. A.

1961 Scored Pottery of the Texas Coastal Bend. BTAS 32:320-325.

1964 A Rockport Black on Gray 011 a from Nueces County. TA 8(2):4.

1964 A Polychrome Vessel from the Texas Coastal Bend. BTAS 35:205-211.

1965 Archeology of the Coastal Bend. Paper given at meeting sponsored by the Houston Archaeologival Society.

1966 A Sma11 Campsite Near Kenedy, Texas. N-HAS 18:3-6.

Campbe11, T. N.

1947 The Johnson Site: Type Site of the Aransas Focus of the Texas Coast. BTAPS 18:40-75.

1952 The Kent-Crane Site: A She11 Midden on the Texas Coast. BTAPS 23: $39-77$

1956 Archeological Materials from Five Islands in the Laguna Madre, Texas Coast. BTAS 27:7-46.

1958 Archeological Remains from the Live Oak Point Site, Aransas County, Texas. TJS 10(4):423-442.

1958 Probable Function of Perforated Oyster Shel1s Found in Aransas Focus Sites. TA 2(2):8.

1960 Archeology of the Central and South Sections of the Texas Coast. BTAS 29:145-176.

1962 Origins of Pottery Types from the Coastal Bend Region of Texas. BTAS 32:331-336. 
Campbe11, T. N. (Cont'd)

1962 Excavations at the Morhiss Site, Victoria County, by The University of Texas, 1938-40. In: An Archaeological Survey of Coleto Creek, Victoria and Goliad Counties, Texas, by A. A. Fox and T. R. Hester. UTSA-CAR-ASR 18:87-85.

1964 Appraisal of the Archeological Resources of Padre Island, Texas. Report submitted to the National Park Service by The University of Texas at Austin (mimeographed).

1973 Systematized Ethnohistory and Prehistoric Culture Sequences of Texas. BTAS 43:1-12.

1975 The Payaya Indians of Southern Texas. Southern Texas Archaeological Association, Special Publication 1.

Campbe11, T. N. and J. Q. Frizze11

1949 Notes on the Ayala Site, Lower Rio Grande Valley, Texas. BTAPS 20:63-72.

Chadderdon, M. F.

1976 An Ana Tysis of Altered Quartzite Cobbles from Victoria County, Texas. La Tierra 3(1):6-15.

Chandler, C. K.

1974 Use Wear Analysis of "Clear Fork" Tools from the Falcon Reservoir Area, Southern Texas. La Tierra 1(4):15-21.

Clauser, C. E.

1947 The Relationship Between a Coastal Algonkin and a Karankawa Cranial Series. Proceedings of the Indiana Academy of Science $57: 18-23$.

Collins, M. B., T. R. Hester and F. Weir

1969 The Floyd Morris Site (41 CF 2), A Prehistoric Cemetery Site in Cameron County, Texas. In: Two Prehistoric Cemetery Sites in the Lower Rio Grande Valley of Texas. BTAS 40:119-146.

Comstock, D. B., K. A. Grombacher and D. S. Dibble

1973. A Study of the Effects of Shell Dredging on the Archeological and Historical Resources of San Antonio Bay, Texas. Texas Archeological Survey Research Report 23.

Corbin, J. E.

1963 Archeological Materials from the Northern Shore of Corpus Christi Bay. BTAS 34:5-30. 
Corbin, J. E. (Con't)

1974 A Model for Cultural Succession for the Coastal Bend Area of Texas. BTAS 45:29-54.

Dibble, D. S.

1974 An Assessment of the Archeological Resources to be Affected by Modifications of the La Quinta Navigation Channel and Basin (Corpus Christi Ship Channe1), Texas. Texas Archeological Salvage Project Research Report 9.

Dillehay, T. D.

1973 An Archeological Reconnaissance of Areas to be Affected by the Proposed Natural Gas Pipeline Company of America, Liquified Natural Gas Project, San Patricio County, Texas. Texas Archeological Salvage Project Research Report 18.

Duffen, W. A.

1940 Morhiss Site. Texas Archaeological News 2:16-18.

Fitzpatrick, W. S., J. Fitzpatrick and T. N. Campbe11

1964 A Rockport Black-on-Gray Vessel from the Vicinity of Corpus Christi, Texas. BTAS 35:193-204.

Fox, A. A. and T. R. Hester

1976 An Archaeological Survey of Coleto Creek; Victoria and Goliad Counties, Texas. UTSA-CAR-ASR 18.

Fox, D. E., R. J. Mallouf, N. O'Malley and W. M. Sorrow

1974 Proposed Cuero I Reservoir. Texas Historical Commission and Texas Water Development Board, Archeological Survey Report 12.

Fritz, G.

1972 Pilot Archeological Field Survey of Cox Bay, Calhoun County, Texas. Matagorda Bay--Estuarine Resource Management Study. Environmental Planning Division of Texas General Land Office.

Gatschet, A. S.

1891 The Karankawa Indians, The Coast People of Texas. Archaealogical and Ethnological Papers of the Peabody Museum, Harvard University $1(2)$.

Gilmore, $K$.

1973 The Keeran Site: The Probable Site of La Salle's Fort St. Louis in Texas. Texas Historical Commission, Office of the State Archeologist, Archeological Report 24. 
Goldstein, M. S.

1940 Some Notes on Texas Crania (abstract). American Journal ob Physical Anthropology 27(3):16.

1957 Skeletal Pathology of Early Indians in Texas. American Journal of Physical Anthropology 15(3):299-312.

Hester, T. R.

1968 Notes on Pottery-Bearing Sites in Southern Texas. The Bull-Roarer, university of Texas Anthropological Society 3(2):9-11.

1969 Archeological Investigations in Kleberg and Kenedy Counties, Texas, in August, 1967. State Building Commission, Archeological Report 15.

1969 Human Bone Artifacts from Southern Texas. American Antiquity $34(3): 326-328$.

1970 Marine Shel1s from Archeological Sites in Southwestern Texas. TJS 22:87-88.

1970 A Folsom Point from the Lower Texas Coast. N-HAS 32:5-6.

1971 Loyola Beach: An Example of Aboriginal Adaptation to the Maritime Environment of the Lower Texas Coast. Florida Anthropologist 23:91-106.

1971 An "Eolith" from Lower Pleistocene Deposits of Southern Texas. BTAS 42:367-372.

1971 A Note on Baked Clay Objects from the Texas Coast. Notebook, university of South Carolina Institute of Archeology and Anthropology 3(1):15-17.

1973 Notes on an Archaeological Site in Kleberg County, Texas. N-HAS $41: 2-6$.

1974 On Fluted Points and South Texas Archeology. TA 18(2):11-14.

1976 Hunters and Gatherers of the Rio Grande Plain and the Lower Coast of Texas. Center for Archaeological Research, The University of Texas at San Antonio.

Hester, T. R. and J. E. Corbin

1975 Two Burial Sites on the Central Texas Coast. TJS 26(3-4):519-528.

Hester, T. R. and T. C. Hi11, Jr.

1971 Notes on Scottsbluff Points from the Texas Coastal Plain. Southwestern Lore $37(1): 27-33$. 
Hester, T. R. and T. C. Hill, Jr. (Con't.)

1971 An Initial Study of a Prehistoric Ceramic Tradition in Southern Texas. PA 16(52):195-203.

1975 Eating Land Snails in Prehistoric Southern Texas: Ethnohistoric and Experimental Data. The Nautilus 89(2):37-38.

Hester, T. R. and R. Parker

1970 The Berclair Site: A Late Prehistoric Component in Goliad County, Southern Texas. BTAS 41:1-24.

Hester, T. R. and R. Rodgers

1971 Additional Data on the Burial Practices of the Brownsville Complex, Southern Texas. TJS 22(4):367-371.

Hester, T. R. and F. Ruecking, Jr.

1969 Additional Materials from the Ayala Site, A Prehistoric Cemetery Site in Hidalgo County, Texas. In: Two Prehistoric Cemetery Sites in the Lower Rio Grande Valley of Texas. BTAS 40:147-157.

Hester, T. R. and H. J. Shafer

1975 An Initial Study of B1ade Technology on the Central and Southern Texas Coast. PA 20(69):175-185.

Hester, T. R. and W. Stanton

1968 Paleo-Indian Materials from a Site on Oso Creek, Nueces County, Texas. N-HAS 25:5-8.

Highley, L., A. Gerstie and T. R. Hester

1977 An Archaeological and Historical Assessment of the Tule Lake Tract, Nueces County, Texas. UTSA-CAR-ASR 27.

Holliday, V. T. and K. A. Grombacher

1973 An Assessment of the Archeological and Historical Resources to be Affected by the Proposed Chiltipin Creek Flood Control Project, San Patricio County, Texas. Texas Archeological Survey Research Report 29.

Kelley, J. C.

1952 Some Geographic and Cultural Factors Involved in Mexican-Southeast Contracts. Selected Papers, 29th International congress of Americanists: 139-144. 
Krieger, A. D.

1953 Recent Developments in the Problems of Relationships Between the Mexican Gulf Coast and the Eastern United States. Huastecos y Totonacos y Sus Vecinos. Sociedad Mexicana de Antropologia 9(2): 497-518.

1956 Food Habits of the Texas Coastal Indians in the Early Sixteenth Century. BTAS 27:47-48.

Landau, $\mathrm{H}$.

1968 The Karankawa Invasion of Texas. International Journal of American Linguistics 34(4):242-258.

Martin, G. C.

n.d. Preliminary Archaeological Survey of a Portion of the Texas Coast made by George C. Martin and Wende1 $1 \mathrm{H}$. Potter in 1927-1928-1929. Privately printed.

1929 Notes on Some Texas Coast Campsites and Other Remains. BTAPS 1: $50-57$.

1930 Two Sites on the Callo del 0so, Nueces County, Texas, BTAPS 2:18-20.

1931 Texas Coastal Pottery. BTAPS 3:53-66.

1936 Mission Tribes of the Mission Nuestra Senora del Refugio. Privately printed. San Antonio.

Mason, J. A.

1935 The Place of Texas in Pre-Columbian Relationships Between the United States and Mexico. BTAPS 7:29-46.

Newcomb, W. W., Jr.

1957 A Reappraisal of the "Cultural Sink" of Texas. Southwestern Journal of Anthropology 12:145-153.

1961 The Indians of Texas. University of Texas Press, Austin. Nunley, J.P.

1973 Toward a Generalized Model of Hunting and Gathering Societies. BTAS 43:13-32.

Patterson, L. W.

1974 Prismatic B1ade Distribution in Texas. La Tierra 1(1):9-14. 
Patterson, L.W. (Con't.)

1974 Three Sites in Jim Wells County. La Tierra 1(2):12-14.

Patterson, P. E. and M. M. Ford

1974 Oso Creek Flood Control Project Area, Nueces County, Texas. Texas Archeological Survey Research Report 35.

Potter, W. H.

1930 Ornamentation on the Pottery of the Texas Coastal Tribes. BTAPS 2:41-44.

Prewitt, E. R.

1974 Preliminary Archeological Investigations in the Lower Rio Grande Delta Area of Texas. BTAS 45:55-65.

Price, W. A. and L. S. Kornicker

1961 Marine and Lagoonal Deposits in Clay Dunes, Gulf Coast, Texas. Journal of Sedimentary Petrology 31(2):245-255.

Reed, C. T.

1937 A Karankawa Fire Implement. BTAPS 9:218-221.

Sayles, E. B.

1935 An Archaeological Survey of Texas. Medallion Papers 17.

Schaedel, R. P.

1949 The Karankawa Indians of the Texas Coast. Southwestern Journal of Anthropology 5(2): 117-137.

Scurlock, D., W. L. Lynn and R. T. Ray

1974 An Assessment of the Archeological Resources of Padre Island National Seashore, Texas. Texas Historical Commission, Office of the State Archeologist, Archeological Report 11.

Sellards, E. H.

1940 Pleistocene Artifacts and Associated Fossils from Bee County, Texas. Bulletin, Geological Society of America 51:1627-1657.

Shafer, H. J. and T. R. Hester

1971 A Study of the Function and Technology of Certain Bifacial Tools from Southern Texas. Texas Historical Survey Committee, Archeological Report 20. 
Sjoberg, A. F.

1953 The Culture of the Tonkawa, A Texas Indian Tribe. TJS 5:280-304.

Stanton, B.

n.d. A Survey of Karankawa Camp Sites near Corpus Christi. A School Study Guide. Corpus Christi Museum, Publication 3.

Story, D. A.

1968 Archeological Investigations at Two Central Texas Gulf Coast Sites. State Building Commission, Archeological Report 13.

Suhm, D. A. and E. B. Jelks

1962 Handbook of Texas Archeology: Type Descriptions. Texas Archeological Society and Texas Memorial Museum.

Suhm, D. A., A. D. Krieger and E. B. Jelks

1954 An Introductory Handbook of Texas Archeology. BTAS 25.

Swanton, J. R.

1924 Southern Contacts of the Indians North of the Guif of Mexico. 20th International Congress of Americanists (Rio de Janeiro): 53-59.

1940 Linguistic Material from the Tribes of Southern Texas and Northeastern Mexico. Smithsonian Institution, Bureau of American Ethnology, Bulletin 127.

WiTley, G. R.

1966 An Introduction to American Archaeology, Volume 1, North and Middle America. Prentice-Hal1, Englewood Cliffs, New Jersey.

Wingate, R. and T. R. Hester

1973 Ten Burials from Green Lake, Texas. Florida Anthropologist $25(3): 119-128$.

Woodbury, G.

1937 Notes on Some Skeletal Remains of Texas. University of Texas Anthropological Papers 1(5):5-16.

Woodbury, G. and E. Woodbury

1935 Prehistoric Skeletal Remains from the Texas Coast. Medallian Papers 18. 


\title{
IV. HISTORICAL ASSESSMENT OF THE PROPOSED PIPELINE ROUTE
}

\author{
Elizabeth Cantu Frkuska
}

The preliminary historical assessment of the projected pipeline route through Hidalgo, Brooks, Jim Wells, Kleberg, Nueces, San Patricio, Refugio and Victoria Counties revealed 52 historic sites and locations and areas of potential historic importance (see Tables 3-10). Other kinds of historical data likely to be encountered in or near the pipeline are: 1) foundations of Spanish houses and associated farm structures, and from later European settlement and ranching/ farming activities; 2) Spanish missions and presidios; 3) abandoned transportation routes and associated camps or relay stations (i.e., cart roads, stagelines, railroad).

Brief county summaries are found in this section. Tables 3-10 provide a comprehensive listing of the presently available historic data. A lengthy historical research bibliography is also provided in this report (see section $V$ ).

\section{Hidalgo County}

Hidalgo County was created from portions of Starr and Cameron Counties in 1852 and named after Miguel Hidalgo Costilla, a Mexican patriot (Jones 1958). Historically the area was explored as early as 1638 by Juanta Garcia de Sepulveda. By 1750 the Hidalgo County area was being colonized by Jose de Escondon. He established Indian missions such as San Joaquin Del Monte a Vista near the town of Hidalgo, which is a "historically sensitive" area (see Table 3). Farming increased the Anglo-American population in the area in approximately 1883 (Chatfield 1893). The majority of towns and cities in proximity of the pipeline were established in the early 1900s as stations or stops along the St. Louis, Brownsville and Mexico Railroad (Allhands 1960). Linn, Texas, however, in the pipeline right-of-way, was established in 1927 as a station on the Texas and New Orleans Railroad (Webb 1952).

See Table 3 for historical information relating to the pipeline route,

\section{Brooks County}

Brooks County was formed in 1911 from sections of Hidalgo, Starr and Live Oak Counties (Webb 1952). The historical marker commemorating this county seat is in the pipeline right-of-way (see Table 4). The county acquired its name from James Abijah Brooks, Captain of the Texas Rangers and a member of the Texas Legislature (Jones 1958). Prior to 1883, the area was inhabited by Mexican colonists who were predominantly "vaqueros" herding wild cattle. The earliest established settlement in Brooks County was that of Falfurrias in 1883 (Webb 1952). The only other organized settlements in the county are the towns of Encino founded in 1903 and Rachal founded in 1913. Both towns are on the TexasNew Orleans Railroad and in the pipeline right-of-way.

See Table 4 for historical information relating to the pipeline route. 
Jim Wells County

In $1911 \mathrm{Jim}$ Wells County was formed from a section of Nueces County and named after James B. Wells (Webb 1952). As early as 1867 individuals investing in large quantities of land were creating cattle industries. Among these large cattle ranches are Tecolote-1867, Ventana Ranch-1867 and Leona Ranch-1875

(Texas Family Land Heritage Registry 1974). One of the last stagelines in Texas (from Alice to Brownsville) crossed Jim Wells County until 1904 (Carter 1972).

See Table 5 for historical information relating to the pipeline route.

\section{Kleberg County}

Kleberg County was named in honor of Robert Justus Kleberg and created in 1913 with Kingsville being the county seat (Webb 1952). Three and one-half centuries earlier Cabeza de Vaca and his followers roamed through the area (Baskett 1907). The hostile Indians and the territorial disputes between Texas and Mexico 1 imited the settlements in the area for some time. Captain Richard King estab1 ished the King Ranch in 1852. It now occupies four-fifths of Kleberg County with its headquarters centered in the Kingsville area (Lea 1957). Between the years 1840 and 1880, hide and tallow plants sprang up throughout the area with main industries centered along the coastal area (see Table 6; Webb 1952). The St. Louis, Brownsville and Mexico Railroad (later the Missouri Pacific) in 1904 came to the Kingsville area on its way across the county.

See Table 6 for historical information relating to the pipeline route.

\section{Nueces County}

Nueces County was named after the Nueces River which derived its name when in 1689 Alonso de Leon saw so many pecan trees along its banks (Jones 1958). The county was organized in 1846 with Corpus Christi as the county seat. In 1519, Alonso Alvarez de Piñeda entered through Corpus Christi Bay and claimed the land for the Spanish Crown (Webb 1952). Jose de Escandon began the first attempt for a permanent settlement on the lower Nueces near present-day Corpus Christi. In the early 1800s the Mexican soldiers constructed Fort Lipantitlan near what is now present-day San Patricio (see Table 7). In an attempt to "Mexicanize" Texas, several forts were established in the early 1830s (Briggs 1971). The Agua Dulce battle site along Agua Dulce Creek near San Patricio commemorates the Texas volunteers killed in 1836 (Jones 1958). In 1903, the junction of the Texas-Mexico and the Brownsville and Mexican Railroad had established the town of Robstown, named after Robert Driscoll.

See Table 7 for historical information relating to the pipeline route.

\section{San Patricio County}

San Patricio County was organized in 1837 and the town of San Patricio was named the county seat (see Table 8). Later in 1893, the town of Sinton became the county seat (Webb 1952). It is thought that parts of the county were traveled as early as 1535 by Cabeza de Vaca. In the mid-eighteenth century, the coastal 
areas of the county were being explored, and by the early nineteenth century James McGloin and John McMullen were settling predominantly Irish families in the coastal bay area (Webb 1952). When the San Antonio-Aransas Pass Railroad was constructed through the county in 1885, the town of Sinton became a station stop. In 1904, the town of Odem was built on the St. Louis, Brownsville and Mexico Railroad and named after David Odem, county sheriff (Webb 1952). The town later became a shipping center.

See Table 8 for historical information relating to the pipeline route.

\section{Refugio County}

Refugio County was one of the original counties formed in the Republic of Texas in 1836. Between 1841 and 1871 sections of Refugio County were split off to form Goliad, Calhoun, San Patricio, Victoria, Bee, Nueces and Aransas Counties, thereby reducing the original county area. Cabeza de Vaca in the early sixteenth century is thought to have traversed the area (Pool 1975). It was not until the late eighteenth century that a Spanish outpost was developed near the present-day town of Refugio (Webb 1952). The Indian mission, Nuestra Señora del Refugio (see Table 9), was constructed in 1793 at the confluence of the San Antonio and Guadalupe Rivers at a time when all other missions were ceasing to exist (Webb 1952; Heusinger 1936). The mission was not successful at its original location and was moved at least once; it is now located on the Mission River in Victoria County. It was not until 1836 that Anglo-Americans began to populate the area, and the majority of these were Irish Catholic settlers. The colony was known as the Power and Heweston Colony and was estab1 ished at the ruins of Mission Nuestra Señora del Refugio.

By 1842 the population of Refugio County had been greatly reduced due to the Texas Revolution, the Battle of Refugio and Mexican raids. Slowly the town of Refugio was rebuilt and became a center for hide and tallow factories (Webb 1952).

In 1850 when John White Bower, an early Texas statesman, died, a memorial grave marker and cemetery were named in honor of him (Jones 1958). This monument and the John White Bower homestead are both in the pipel ine right-of-way (see Table 9).

See Table 9 for historical information relating to the pipeline route.

\section{Victoria County (southwestern part)}

Victoria County was created in 1836 with Victoria being chosen as the county seat. The first European settlement in Texas was built by the French in 1865 along Garcitas Creek and was used as a base for defenses against the Indians and a base for exploration (Gilmore 1973). Between the years of 1722 and 1726 a Spanish presidio and mission of Espiritu Santo were established nearby. The mission was moved from its original location near the fort to an area near the Guadalupe River in 1726 (Briggs 1971). In the middle 1800s the De La Garza family began using a plot of land which is in the pipeline right-of-way (see Table 10). Bloomington was settled in 1907 as a station on the Missouri Pacific Railroad. The territory originally was a part of the Traylor Ranch in southeastern Victoria County (Webb 1952).

See Table 10 for historical information relating to the pipeline route. 
TABLE 3. HISTORICAL SITES IN HIDALGO COUNTY +

\begin{tabular}{|c|c|c|c|c|}
\hline Site Number* & Description & Type*** & Milepost & $\begin{array}{l}\text { Distance from } \\
\text { Pipeline (Miles) }\end{array}$ \\
\hline $\mathrm{H}-1$ & $\begin{array}{l}\text { Town of Hidalgo-City Park } \\
\text { 1852. }\end{array}$ & 1 & .70 & $1.10 \mathrm{NW}$ \\
\hline $\mathrm{H}-2$ & $\begin{array}{l}\text { John Closner Home } \\
\text { Young and 13th Streets }\end{array}$ & 1 & .70 & $1.10 \mathrm{NW}$ \\
\hline $\mathrm{H}-3$ & $\begin{array}{l}\text { 01d Hidalgo County Courthouse } \\
1303 \text { McAllen Street }\end{array}$ & 1 & .70 & $1.10 \mathrm{NW}$ \\
\hline$H-4$ & $\begin{array}{l}\text { 01d Hidalgo Post 0ffice } \\
\text { Building Northeast corner of } \\
\text { 13th and McAllen Streets }\end{array}$ & 1 & .70 & $1.10 \mathrm{NW}$ \\
\hline$H-5$ & $\begin{array}{l}\text { Mission San Joaquin del Monte } \\
\text { a Vista-City Park, 13th Street } \\
\text { and 0ld Military Road } \\
\text { Established in } 1749\end{array}$ & 1 & 1.34 & $1.18 \mathrm{NW}$ \\
\hline$H-6$ & $\begin{array}{l}\text { San Juan, Texas-1909 on the } \\
\text { Missouri Pacific Raitroad }\end{array}$ & 4 & 12.01 & $3.4 \mathrm{~W}$ \\
\hline $\mathrm{H}-7$ & $\begin{array}{l}\text { Alamo, Texas-on the Missouri } \\
\text { Pacific Railroad }\end{array}$ & 4 & 12.01 & $1.00 \mathrm{~W}$ \\
\hline$H-8$ & $\begin{array}{l}\text { San Juan Plantation Head- } \\
\text { quarters }\end{array}$ & 1 & 1.72 & $1.0 \mathrm{NW}$ \\
\hline $\mathrm{H}-9$ & Edinburg, Texas-1890 & 4 & 20.51 & $5.00 \mathrm{~W}$ \\
\hline $\mathrm{H}-10$ & $\begin{array}{l}\text { Hidalgo County-Courthouse } \\
\text { Grounds }\end{array}$ & 1 & 20.51 & $5.00 \mathrm{~W}$ \\
\hline$H-11$ & $\begin{array}{l}\text { El Sal de Rey, C.S.A.-Civil } \\
\text { War Marker }\end{array}$ & 1 & 20.51 & $5.00 \mathrm{~W}$ \\
\hline$H-12$ & $\begin{array}{l}\text { Hidalgo County Jai1-107 } \\
\text { E. McIntyre }\end{array}$ & 1 & 20.51 & $5.00 \mathrm{~W}$ \\
\hline $\mathrm{H}-13$ & Laguna Seca Ranch & 1 & 30.16 & $2.50 W$ \\
\hline$H-14$ & 01d La Coma Ranch Headquarters & 1 & 35.16 & $.24 * \star$ \\
\hline$H-15$ & El Sal del Rey & 1 & 39.03 & $3,00 \mathrm{E}$ \\
\hline
\end{tabular}


Table 3. (continued)

Site Number*

Description

Type*** Milepost

Distance from

H-76

Linn, Texas-1927 Station on the Texas-New Orleans Railroad

$4 \quad 39.76$

$.25^{\star \star}$

$\mathrm{H}-17$

Collapsed Brick StructurePossible Station on Southern Pacific Railroad

$4 \quad 51.40$ Pipeline (Miles)

Total Pipeline Mileage in Hidalgo County - 55.31

Total Number of Official Historic Markers - 26

Total Number of National Register Historic Districts - 1

+ Within eight miles any direction, paralleling the proposed pipeline route

* Tenneco Map Designation

** In Pipeline Route

*** Type: (1) Official Historical Marker, (2) National Register Historic District, (3) NewTy Discovered Historic Site, (4) Potential Historic Site or Area 
TABLE 4. HISTORICAL SITES IN BROOKS COUNTY'

\begin{tabular}{|c|c|c|c|c|}
\hline Site Number* & Description & 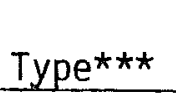 & Milepost & $\begin{array}{l}\text { Distance from } \\
\text { Pipeline (Miles) }\end{array}$ \\
\hline$H-18$ & $\begin{array}{l}\text { Rachal, Texas-1913, a stop } \\
\text { on the Texas-New Orleans } \\
\text { Railroad }\end{array}$ & 4 & 62.76 & $.40 * *$ \\
\hline $\mathrm{H}-19$ & $\begin{array}{l}\text { Encino, Texas- } 1903 \\
\text { on the Texas-New Orleans } \\
\text { Railroad }\end{array}$ & 4 & 66.24 & $.15^{\star *}$ \\
\hline$H-20$ & $\begin{array}{l}\text { Brooks County-March 11, } 1911 \\
\text { formed from Hidalgo, Starr } \\
\text { and Zapata Counties }\end{array}$ & 1 & 75.43 & $.07 * *$ \\
\hline$H-21$ & Flowe 11a & 1 & 86.62 & $1.81 \mathrm{E}$ \\
\hline$H-22$ & $\begin{array}{l}\text { City of Falfurrias-Pioneer } \\
\text { Park }\end{array}$ & 1. & 86.62 & $2.82 \mathrm{~W}$ \\
\hline$H-23$ & $\begin{array}{l}\text { Captain J. A. Brooks- } \\
\text { Falfurrias Cemetery }\end{array}$ & 1 & 86.62 & 2.66 WNW \\
\hline$H-24$ & Don Pedro Jaramillo Shrine & 1 & 88.40 & $1.43 \mathrm{~W}$ \\
\hline
\end{tabular}

Total Pipeline Mileage in Brooks County - 33.93

Total Number of Official Historic Markers - 5

Total Number of National Register Historic Districts - 0

${ }^{\dagger}$ Within eight miles paralleling the proposed pipeline route

*Tenneco Map Designation

**In Pipeline Route

$\star \star \star *$ Type: (1) Official Historical Marker, (2) National Register Historic District,

(3) Newiy Discovered Historic Site, (4) Potential Historic Site or Area 
TABLE 5. HISTORICAL SITES IN JIM WELLS COUNTY ${ }^{\dagger}$

Site Number* $\mathrm{H}-25$
Premont, Texas-on the Texas-

New Orleans Railroad
Type** Milepost

496.62

$3.16 \mathrm{~W}$

Total Pipeline Mileage in Jim Wells County - 15.46

Total Number of Official Historic Markers - 3

Total Number of National Register Historic Districts - 0

+ Within eight miles paralleling the proposed pipeline route

* Tenneco Map Designation

** Type: (1) Official Historical Marker, (2) National Register Historic District,

(3) NewTy Discovered Historic Site, (4) Potential Historic Site or Area

TABLE 6. HISTORICAL SITES IN KLEBERG COUNTY ${ }^{\dagger}$

$\begin{array}{ccccc}\text { Site Number* } & \text { Description } & \text { Type** } & \text { Milepost } & \begin{array}{c}\text { Distance from } \\ \text { Pipeline (Miles) }\end{array} \\ \text { H-26 } & \text { Hide and Tal low Plant } & 1 & 111.19 & .40^{\star *} \\ \text { H-27 } & \text { King Ranch-Entrance } & 2 & 111.19 & 1.70 \mathrm{E}\end{array}$

Total Pipeline Mileage in Kleberg County - 13.80

Total Number of Official Historic Markers - 18

Total Number of National Register Historic Districts - 2

† Within eight miles paralleling the proposed pipeline route

* Tenneco Map Designation

** In Pipeline Route

*** Type: (1) Official Historical Marker, (2) National Register Historic District,

(3) New1y Discovered Historic Site, (4) Potential Historic Site or Area 
TABLE 7. HISTORICAL SITES IN NUECES COUNTY ${ }^{\dagger}$

\begin{tabular}{|c|c|c|c|c|}
\hline Site Number* & Description & Type ${ }^{\star \star \star}$ & Milepost & $\begin{array}{c}\text { Distance from } \\
\text { Pipeline (Miles) }\end{array}$ \\
\hline$H-28$ & King Ranch - 1853 & 2 & & \\
\hline$H-29$ & $\begin{array}{l}\text { Agua Dulce, Texas-on the } \\
\text { Texas-Mexican Rajlroad }\end{array}$ & 4 & 129.88 & $4.85 \mathrm{~W}$ \\
\hline$H-30$ & $\begin{array}{l}\text { Banquete, C.S.A.-Civi1 } \\
\text { War Marker }\end{array}$ & 1 & 133.32 & $.80 * * W$ \\
\hline $\mathrm{H}-31$ & $\begin{array}{l}\text { Agua Dulce Battlesite- } \\
\text { Texas volunteers ki1led } \\
\text { in fight with General } \\
\text { Jose Urrea's Mexican } \\
\text { Cavalry, March 2, } 1836\end{array}$ & 1 & 133.32 & $\begin{array}{l}4.57 \mathrm{NW} \text { (east } \\
\text { part of Aqua } \\
\text { Dulce) }\end{array}$ \\
\hline $\mathrm{H}-32$ & $\begin{array}{l}\text { Fort Lipantitlan-early } \\
\text { 1830s }\end{array}$ & 1 & 137.10 & $\begin{array}{l}8.12 \text { NW (west } \\
\text { bank of Nueces } \\
\text { River) }\end{array}$ \\
\hline $\mathrm{H}-33$ & $\begin{array}{l}\text { Robstown-1903; junction } \\
\text { of the Texas-Mexican and } \\
\text { Brownsville-Mexican } \\
\text { Railroads }\end{array}$ & 4 & 138.42 & $5.75 \mathrm{SE}$ \\
\hline
\end{tabular}

Total Pipeline Mileage in Nueces County - 24.30

Total Number of Historic Markers - 21

Total Number of National Register Historic Districts - 1

+Within eight miles paralleling the proposed pipeline route

* Tenneco Map Designation

** In Pipeline Route

*** Type: (1) Official Historical Marker, (2) National Register Historic District,

(3) NewTy Discovered Historic Site, (4) Potential Historic Site or Area 
TABLE 8. HISTORICAL SITES IN SAN PATRICIO COUNTY ${ }^{\dagger}$

\begin{tabular}{clccc} 
Site Number* & \multicolumn{1}{c}{ Description } & Type** & Milepost & $\begin{array}{c}\text { Distance from } \\
\text { Pipeline (Miles) }\end{array}$ \\
H-34 & $\begin{array}{l}\text { Odem, Texas-1904 townsite on } \\
\text { the St. Louis, Brownsvitle } \\
\text { and Mexico Railroad }\end{array}$ & 4 & 149.13 & $3.2 \mathrm{SE}$ \\
H-35 & $\begin{array}{l}\text { Sinton, Texas-1885 station } \\
\text { on the San Antonio-Aransas } \\
\text { Pass Railroad }\end{array}$ & 4 & 157.75 & $3.0 \mathrm{SE}$ \\
$\mathrm{H}-36$ & $\begin{array}{l}\text { San Patricio County- } \\
\text { Courthouse Grounds }\end{array}$ & 1 & 157.75 & $3.0 \mathrm{SE}$
\end{tabular}

Total Pipeline Mileage in San Patricio County - 22.22

Total Number of Official Historic Markers - 7

Total Number of National Register Historic Districts - 1

† Within eight miles paralleling the proposed pipeline

* Tenneco Map Designation

** Type: (1) Official Historical Marker, (2) National Register Historic District,

(3) Newly Discovered Historic Site, (4) Potential Historic Site or Area 
TABLE 9. HISTORICAL SITES IN REFUGIO COUNTY ${ }^{\dagger}$

\begin{tabular}{|c|c|c|c|c|}
\hline Site Number* & Description & 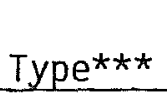 & Milepost & $\begin{array}{l}\text { Distance from } \\
\text { Pipeline (Miles) }\end{array}$ \\
\hline$H-37$ & $\begin{array}{l}\text { Sal7y Scull-intersection of } \\
\text { U.S. } 183 \text { and SH } 202\end{array}$ & 1 & 180.88 & $1.4 \mathrm{E}$ \\
\hline $\mathrm{H}-38$ & $\begin{array}{l}\text { Amon B. King-King's Park } \\
1836\end{array}$ & 1 & 180.88 & $3.0 \mathrm{SE}$ \\
\hline$H-39$ & $\begin{array}{l}\text { King's Men Monument-Mount } \\
\text { Calvary Cemetery }\end{array}$ & 1 & 180.88 & $3.0 \mathrm{SE}$ \\
\hline$H-40$ & $\begin{array}{l}\text { Refugio County-Courthouse } \\
\text { Grounds - } 1837\end{array}$ & 1 & 180.88 & $3.0 \mathrm{SE}$ \\
\hline $\mathrm{H}-41$ & $\begin{array}{l}\text { Site of Home of Captain Ira } \\
\text { Westover-608 Commerce Street } \\
1835\end{array}$ & 1 & 180.88 & $3.0 \mathrm{SE}$ \\
\hline$H-42$ & $\begin{array}{l}\text { Colonel A. M. Hobby-Court- } \\
\text { house Grounds }\end{array}$ & 1 & 180.88 & $3.0 \mathrm{SE}$ \\
\hline$H-43$ & $\begin{array}{l}\text { Mission Nuestra Señora del } \\
\text { Refugio-Grounds of Our Lady } \\
\text { of Refuge Church, S. Alamo } \\
\text { Street }\end{array}$ & 1 & 180.88 & $3.5 \mathrm{SE}$ \\
\hline$H-44$ & $\begin{array}{l}\text { Line Shack-(1890s) possible } \\
\text { Welder Homestead }\end{array}$ & 4 & 191.66 & $.03^{\star *}$ \\
\hline$H-45$ & $\begin{array}{l}\text { Tenneco Number 8-19th century } \\
\text { pottery from Ohio-possible } \\
\text { homestead }\end{array}$ & 3 & 197.98 & $1.0 * \mathrm{SE}$ \\
\hline$H-46$ & Monument-Memorial Grave Marker & 3 & 197.98 & $.83^{*} \mathrm{SE}$ \\
\hline$H-47$ & Urban House & 3 & 199.98 & $.85^{\star} \mathrm{NW}$ \\
\hline$H-48$ & $\begin{array}{l}\text { John White Bower-Bower } \\
\text { Cemetery, died } 1850\end{array}$ & 1 & 199.98 & $.20^{\star *}$ \\
\hline$H-49$ & John White Bower Homestead & 1 & 199.98 & $.07 \star \star$ \\
\hline
\end{tabular}

Total Pipeline Mileage in Refugio County - 35.16

Total Number of Official Historic Markers - 12

Total Number of National Register Historic Districts - 1

+ Within eight miles paralleling the proposed pipeline route

* Tenneco Map Designation

** In Pipeline Route

*** Type: (1) Official Historical Marker, (2) National Register Historic District,

(3) NewTy Discovered Historic Site, (4) Potential Historic Site or Area 
TABLE 10. HISTORICAL SITES IN VICTORIA COUNTY ${ }^{\dagger}$

\begin{tabular}{clccc} 
Site Number* & \multicolumn{1}{c}{ Description } & Type*** & Milepost & $\begin{array}{c}\text { Distance from } \\
\text { Pipeline (Miles) }\end{array}$ \\
\hline$H-50$ & $\begin{array}{l}\text { De La Garza Homestead } \\
\text { and Dump }\end{array}$ & 4 & 200.73 & $.10^{\star *}$ \\
$H-51$ & $\begin{array}{l}\text { De La Garza Cemetery- } \\
1850\end{array}$ & 4 & 200.73 & $.05^{\star \star}$ \\
$H-52$ & Homestead & 4 & 208.00 & $.50^{\star \star}$
\end{tabular}

Total Pipeline Mileage in Victoria County - 14.11

Total Number of Official Historic Markers - 57

Total Number of National Register Historic Districts - 0

${ }^{+}$Within eight miles paralleling the proposed pipeline route

* Tenneco Map Designation

** In Pipeline Route

*** Type: (1) Official Historical Marker, (2) National Register Historic District,

(3) NewTy Discovered Historic Site, (4) Potential Historic Site or Area 


\section{RESEARCH BIBLIOGRAPHY: HISTORY}

Elizabeth Cantu Frkuska

Abbreviations Used

SWHQ Southwestern Historical Quarterly

UTSA-CAR The University of Texas at San Antonio, Center for Archaeological Research

-ASR Archaeological Survey Report

Allhands, J. L.

1960 Railroads to the Rio. The Anson Jones Press, Salado.

Anonymous

1912 A Brief Story of Falfurrias. Falfurrias Jersey Dairy Company, Falfurrias.

Baskett, J. N.

1907 A Study of the Route of Cabeza de Vaca. Texas Historical Association Quarterly 10:246-279.

Bass, S. W.

1931 The History of Kleberg County. M.A. Thesis, The University of Texas, Austin.

Bierman, M. M.

1948 A History of Victoria, Texas 1824-1900, M.A. Thesis, The University of Texas, Austin.

Braman, D. E. E.

1957 Braman's Information about Texas. J. B. Lippincott, Philadelphia.

Branda, E. S., Editor

1976 The Handbook of Texas, A Supplement. The Texas State Historical Association, Austin.

Briggs, A. K.

1971 Archeological Resources in the Texas Coastal Lowlands and Littoral. Texas Historical Survey Committee and Texas Water Development Board. 
Bolton, H. E.

1916 The Beginnings of Mission Nuestra Señora de Refugio. SWHQ $19: 400-404$.

1921 The Spanish Borderlands; Texas and the Mexican War. Yale University Press, New Haven.

1925 Spanish Exploration in the Southwest, 1542-1706. New York.

Brown, J.H.

1892- History of Texas 1685-1892. 2 vol. Bechold and Company,

1893 St. Louis.

Brune, $G$.

1975 Major and Historical Springs of Texas. Texas Water Development Board, Report 189.

Burke, J.W.

1971 Missions of Oed Texas. A. S. Barnes, South Brunswick.

Carter, K. T.

1972 Stagecoach Inns of Texas. Texian Press, Waco.

Chatfield, (Lieut.) W. H.

1893 Twin Cities of the Border and the Country of the Lower Rio Grande. E. P. Brandao, New Orleans.

Clark, J. and E. Scott

1955 The Texas Gulf Coast, Its History and Development. 4 vols. Lewis Historical Publishing Company, New York.

Clark, R. C.

1907 The Beginnings of Texas 1684-1718. Bulletin of The University of Texas 98, Austin.

Coastal Management Program

1975 The State of Texas, General Land Office, Coastal Management Program. [See Plates $8 A, B$ for data on historical and archaeological sites on the upper and lower coast.] 
Connor, S. V.

1975 Texas in 1776: A Historical Description. Jenkins Publishing Company, Austin.

Crawford, P. P.

1925 The Beginning of Spanish Settlement in the Lower Rio Grande valley. M.A. Thesis, The University of Texas at Austin.

Crofford, L. H.

1963 Pioneers on the Nueces. Naylor Company, San Antonio.

De Garmo, Mrs. F. A.

1951 Pathfinders of Texas, 1836-1846, Being the Stories of Pioneer Families that Builded Well for Nueces County and Corpus Christi. Von Boeckmann-Jones, Austin.

Deviney, M. L.

1935 The History of Nueces County to 1850. M.A. Thesis, The University of Texas at Austin.

Dexter, $W . W$.

1903 The coast County of Texas. Ra in Lithograph Company, Orange.

Dobie, J.F.

1929 A Vaquero of the Brush Country. The Southwest Press, Dallas.

Dunn, J. B.

1932 Previous Trails of Texas. The Southwest Press, Dallas.

Dyer, L. N.

1934 Early History of San Patricio County. Martin and Martin, Sinton.

1938 History of Brooks County. M.A. Thesis, Texas College of Arts and Industries, Kingsville.

Elliot, C.

1955 Theses on Texas History. The Texas State Historical Association, Austin. 
Fehrenbach, T. R.

1968 Lone Star. MacMillan, New York.

Fields, F. T. 1962 Texas Sketchbook. Revised Edition. Humble 0il and Refining
Company, Houston.

Flanagan, $\mathrm{S}$.

1974 Trailing the Longhorns a Century Later. Madrona Press, Austin. Fontaine, K. (editor)

1976 The National Register of Historic Places in Texas 1968-1975. Texas Historical Commission, Austin.

Foscue, E. J.

1939 Historical Geography of the Lower Rio Grande Valley of Texas. Texas Geographic Magazine, 111-1, Spring.

Fox, A. A. and T. R. Hester

1976 An Archaeological Survey of Coleto Creek, Victoria and Goliad Counties, Texas. Center for Archaeological Research, The University of Texas at San Antonio, Archaeological Survey Report 18.

Garrett, J. K.

1969 Green Flag Over Texas. Pemberton Press, Austin-New York. Gatschet, A. S.

1891 The Karankawa Indians. Archaeological and Ethnological Papers of the Peabody Museum 1(2), Cambridge.

Gerstle, A., T. C. Kelly and C. Assad

1978 The Fort Sam Houston Project: An Archaeological and Historic Assessment. Center for Archaeological Research, The University of Texas at San Antonio. Archaeological Survey Report 40.

Gilliland, M. T.

1964 Rincon (Remote Dwelling Place). Privately printed, Brownsville. Gilmore, K.

1973 The Keeran Site: The Probable Site of La Salle's Fort St. Louis in Texas. Texas Historical Commission, office of the State Archeologist Report 24. 
Grimm, A. G.

1968 Llanos Mesteñas, Mustang Plains. Texian Press, Waco.

Guice, C., editor and translator

1955 Texas in 1804. SWHQ 59:46-56.

Hester, T. R., editor

1975 Archaeological and Historical Resources in the San AntonioGuadalupe River Basins: A Preliminary Statement. UTSA-CAR Regional Studies 1.

Huesinger, E. W.

1936 Early Explorations and Mission Establishments in Texas. The Naylor Company, San Antonio.

1952 Hidalgo County Centennial, 1852-1952. Official Historical Program, December 7-13.

Highley, L., A. Gerstle and T. R. Hester

1977 An Archaeological and Historical Assessment of the Tule Lake Tract, Neuces County, Texas. UTSA-CAR-ASR 27.

Hunter, J. M.

1932 Edinburg and Hidalgo County Then and Now. Frontier Times, August.

Huson, $H$.

1936 The Refugio Colony and Texas Independence: An Address... on the Occasion of the Refugio County Centennial Celebration at Refugio, Texas, October Twenty-first, Nineteen Hundred and Thirty-six. Refugio Timely Remarks.

1955 Refugio: A Comprehensive History of Refugio County from Aboriginal Time to 1955. 2 vol. The Rooke Foundation, Woodsboro.

1974 Captain Phillip Dimmitt's Commandancy of Goliad, 1835-1836. Von Boeckmann-Jones, Austin.

Jenkins, J. H.

1965 Cracker Barrel Chronicles. The Pemberton Press, Austin.

1973 The Papers of the Texas Revolution, 1835-1836. 10 vols. (General Editor), Presidial Press, Austin. 
Jones, W. M.

1958 Texas History Carved in Stone. Monument Publishing Company, Houston.

King, D.

1953 Ghost Towns of Texas. Naylor Company, San Antonio.

Lea, $T$.

1957 The Fabulous King Ranch, an American Epic. Life Magazine, JuTy 8, 1957.

1957 The King Ranch. 2 vols. Little, Brown and Company, New York.

Maddox, W. E.

1955 History of Donna Community. M.A. Thesis, Texas College of Arts and Industries, Kingsville.

Martin, G. C.

1963 The Indian Tribes of the Mission Neustra Señora del Refugio. Privately printed, San Antonio. Reprinted 1972, Bootstrap Press, Corpus Christi.

McCampbe11, C.

1935 Nueces County Originally Covered Vast Area. Frontier Times, Apri1, 1935.

Moore, F., Jr.

1840 Map and Description of Texas, Containing Shetches of Its History, Geology, Geography, and Statistics. H. Tanner, Philadelphia.

Moore, R. L.

1937 History of Refugio County. M.A. Thesis, The University of Texas, Austin.

Morris, L.

1953 Pictorial History of Victoria and Victoria County. Clemens Printing, San Antonio.

Neighbores, C. Y.

1942 The Oed Town of St. Mary's on Copano Bay and Some Interesting People who Once Lived There. Southwest Texas State Teachers College, San Marcos. 
Newcomb, W. W., Jr.

1961 The Indians of Texas from Prehistoric to Modern Times. University of Texas Press, Austin.

Norris, W. C.

1952 History of Hidalgo County. M.A. Thesis, Texas College of Arts and Industries, Kingsville.

Oberste, Msgr. W. H.

1942 History of Refugio Mission. Refugio Timely Remarks, Refugio.

Padilla, J. A.

1920 Texas in 1820. Translated by Mattie Austin Hatcher. SWHQ 23:68.

Pierce, R. C.

1917 A Brief History of the Lower Rio Grande Valley. Collegiate Press, Menasha.

Pierce, G. S.

1969 Texas Under Arms: The Camps, Posts, Forts, and Military Towns of the Republic of Texas, 1836-1846. Encino Press, Austin.

Pollard, N. V.

1945 The History of Jim Wells County. M.A. Thesis, Texas College of Arts and Industries, Kingsville.

Pool, W. C.

1975 A Historical Atlas of Texas. Encino Press, Austin.

Reed, S. G.

1941 A History of the Texas Railroad. The St. Clair Publishing Company, Houston.

Richards, E. C.

1947 Story of Banquete, Texas: A Background for the Educational System. M.A. Thesis, Texas College of Arts and Industries, Kingsville.

Roemer, F.

1935 Texas. Standard Printing Company, San Antonio. 
Santleben, A.

1910 A Texas Pioneer, Early Staging and Overland Freighting on the Frontiers of Texas and Mexico. New York.

Scott, F. J.

1935 Spanish Land Grants in the Lower Rio Grande Valley. M. A. Thesis, The University of Texas, Austin.

1966 Historical Heritage of the Lower Rio Grande. Texian Press, Austin.

Scott, $0 . R$.

1912 Sinton. Texas Magazine, August.

1934 History of Hidalgo County, 1749-1852. M.A. Thesis, Texas Christian University, Fort Worth.

1936 Sketch of Refugio County. In: Souvenir Program, Refugio County Centennial Celebration at Refugio... with a Guide to Historical

Sites in Refugio County. Refugio.

Stambaugh, J. L. and L. J. Stambaugh

1954 The Lower Rio Grande Valley of Texas. Naylor Company, San Antonio.

Taylor, F. J. and N. C. Wilson

1952 Southern Pacific, the Roaring Story of a Fighting Railroad. McGraw-Hi11 Book Company, Inc., New York.

Taylor, P. S.

1934 An American Mexican Frontier: Nueces County, Texas. University of North Carolina Press, Chapel Hill.

The Texas Almanac

1857-1937 and 1939-to present

A. H. Be1o Corporation, Dallas.

Texas Department of Agriculture

1974 Texas Family Land Heritage Registry. Vo1. 1. Austin.

1975 Texas Family Land Heritage Registry. Vo1. 2. Austin.

Texas Historical Commission

1975 Guide to Official Texas Historical Markers. Austin. 
Thonhoff, R. H. and R. S. Weddle

1976 Drama and Conflict: The Texas Saga of 1776. Madrona Press Inc., Austin.

Tilioson, C.

1947 Lipantitlan. Frontier Times, October.

Toulouse, J. and J. R. Toulouse

1936 Pioneer Posts of Texas. Compiled from Records of the war Department. Naylor Press, San Antonio.

U. S. Department of the Interior

1973 Historic Preservation in Texas: The Comprehensive Statewide

Historic Preservation Plan for Texas. Vol. 1. Published jointly by the Texas Historical Commission and the Office for Archeology and Historic Preservation.

Vigness, D. M.

1948 The Lower Rio Grande Valley, 1836-1846. M. A. Thesis, The University of Texas, Austin.

1965 The Revolutionary Decades. Austin.

Walburton, Sister M. R.

1939 A History of the $0^{\prime}$ Connor Ranch, 1834-1939. M.A. Thesis, Catholic University of America, Washington.

Watson, Mrs. J.

1931 The Lower Rio Grande of Texas and Its Builders. Privately printed, Mission.

Webb, W. P.

1935 The Texas Rangers, A Century of Frontier Defense. The University of Texas Press, Austin.

1952 The Handbook of Texas. The Texas Historical Association. Vol. 1 $(A-K)$ and Vol. $2(L-Z)$. Texas State Historical Society, Austin.

Welch, J. R.

1972 Historic Sites of Texas. Texian Press, Waco.

Wortham, L. J.

1924 A History of Texas. 5 vols. Fort Worth. 
Yelvington, $\mathrm{H}$.

1934 Irish Pioneers of San Patricio. Frontier Times, September. Yoakum, $H$.

1856 History of Texas from its First Settlement in 1685 to its Annexation to the united States in 1846. 2 vols. Redfield. 